\title{
Picoplankton abundance and cytometric group diversity along a trophic and latitudinal lake gradient
}

\author{
M. Romina Schiaffino ${ }^{1, *}{ }^{,}$Josep M. Gasol ${ }^{2}$, Irina Izaguirre ${ }^{1}$, Fernando Unrein ${ }^{3}$ \\ ${ }^{1}$ Departamento de Ecología, Genética y Evolución, Facultad de Ciencias Exactas y Naturales, \\ Universidad de Buenos Aires - IEGEBA (CONICET-UBA), Ciudad Universitaria, C1428EHA Buenos Aires, Argentina \\ ${ }^{2}$ Institut de Ciències del Mar-CSIC, Passeig Marítim de la Barceloneta 37-49, 08003 Barcelona, Catalonia, Spain \\ ${ }^{3}$ IIB-INTECH (Instituto de Investigaciones Biotecnológicas-Instituto Tecnológico de Chascomús)-CONICET, 7130, \\ Chascomús, Argentina
}

\begin{abstract}
The picoplankton (PP) is responsible for major ecosystem functions in most aquatic environments. However, not much is known about the factors that regulate its total abundance and community structure. Using flow cytometry (FC) to detect particles based on their pigments and nucleic-acid content, we described and quantified the photosynthetic picoplankton (PPP) and the heterotrophic bacterioplankton (HB) populations (or groups) composing PP in 32 water bodies located along a trophic and latitudinal gradient in the Argentinean Patagonia to determine flowcytometrically defined community structures. We set out to identify the environmental variables regulating total PP abundance, group structure and cytometric diversity. We identified a total of 28 different cytometric populations within the HB, 14 of phycoerythrin (PE)-rich picocyanobacteria (Pcy), 8 of phycocyanin (PC)-rich Pcy, and 41 of picoeukaryotes (Peuk) in the different water bodies, with average $3.9 \mathrm{HB}$ and $4.6 \mathrm{PPP}$ groups per water body. We found a strong influence of environmental factors and a less marked effect of latitude on PP structure. HB and PPP abundances decreased towards higher latitudes but their cytometric diversity did not, whereas HB, PCrich Pcy and Peuk abundances together with PPP diversities increased with higher values of chlorophyll a (chl a). The relative contribution of PE-rich Pcy to total Pcy decreased with chl a, whereas the relative contribution of PC-rich Pcy and the number of PC-rich cytometric populations increased with chl a values. Peuk prevailed over Pcy with increasing trophic status and light attenuation, whereas HB prevailed over PPP with increasing trophic status.
\end{abstract}

KEY WORDS: Flow cytometry · Picoplankton · Bacteria · Picocyanobacteria · Picoeukaryotes · Patagonian water bodies $\cdot$ Latitudinal gradient

\section{INTRODUCTION}

The picoplankton (PP), which comprises plankton with cell diameters between $<0.2$ and $3 \mu \mathrm{m}$, is an important component of aquatic food webs and plays a significant biogeochemical and ecological role in aquatic environments (e.g. Cotner \& Biddanda 2002, Richardson \& Jackson 2007). This small size fraction includes prokaryotic and eukaryotic planktonic autotrophs and heterotrophs (e.g. Johnson \& Sieburth 1982, Burns \& Stockner 1991). It is distributed worldwide and is ubiquitous in all types of water bodies of all trophic levels (e.g. Stockner \& Antia 1986, Stockner 1991, Weisse 1993, Bell \& Kalff 2001). The activity of autotrophic and heterotrophic PP constitutes an essential source of energy that fuels the microbial loop (Pomeroy 1974, Azam et al. 1983). PP provides a linkage among dissolved organic carbon, nutrients and conventional food webs through predator-prey interactions (e.g. Caron et al. 1985, Stockner \& Antia 1986, Callieri \& Stockner 2002, Sherr \& Sherr 2002). 
Picoplankton distribution and abundance can change dramatically depending on the interplay between biotic and abiotic factors (Weisse \& Kenter 1991, Hall \& Vincent 1994). The abundance of PP seems particularly controlled by nutrient availability (Stockner \& Shortreed 1991), water temperature (Burns \& Stockner 1991), and light conditions in the water column (Craig 1987, Pick \& Agbeti 1991). The research accumulated to date on the abundance, biomass and production of heterotrophic bacterioplankton (HB) and photosynthetic PP (PPP: comprising picocyanobacteria, Pcy, and picoeukaryotes, Peuk) has revealed some general patterns. Among them, HB abundance and production are commonly observed to increase with increasing trophic status (this means from oligotrophic to eutrophic) (Bird \& Kalff 1984, Cole et al. 1988, Gasol \& Duarte 2000), and PPP abundance and production follow the same trend (Bell \& Kalff 2001), although their contribution to total phytoplankton biomass and production decreases with trophic status, both in marine and freshwater ecosystems (Stockner 1988, 1991, Søndergaard 1991, Agawin et al. 2000, Bell \& Kalff 2001, Callieri \& Stockner 2002, Callieri 2008). Phycoerythrin (PE)-rich cells dominate among Pcy in oligotrophic and transparent lakes, whereas phycocyanin (PC)-rich cells tend to prevail in eutrophic and turbid water bodies (Pick 1991, Vörös et al. 1998, Camacho et al. 2003, Stomp et al. 2007). Pcy biomass has also been negatively related to indices of eutrophication (Burns \& Galbraith 2007) and Pcy tend to be replaced by Peuk at high chlorophyll $a$ (chl a) values (Li 2009).

Most of this knowledge on PP ecology was gained after epifluorescence microscopy was introduced in the field (Daley \& Hobbie 1975) and after flow cytometry (FC) was brought from clinical biology into microbial ecology (Olson et al. 1985, Chisholm et al. 1988). FC has become one of the most powerful tools for the study of aquatic microbial communities (Gasol \& del Giorgio 2000, Lomas et al. 2011) as it provides important and detailed PP characterization based on differences in individual cell fluorescence (related to nucleic acid or pigment content) and in size- and granularity-derived signals, so that the cell-specific properties of aquatic microbes can be measured in hundreds of cells at a time. Other components of the planktonic communities of lakes, such as cyanobacterial microcolonies (consisting of 4 to 50 picocyanobacterial cells) (Callieri 2010) and particle-attached bacteria (e.g. Friedrich et al. 1999, A. Malits unpubl. data) can also be enumerated by FC, albeit with some difficulties. The former are identified by their relatively high autofluorescence, compared with unicellular Pcy (Crosbie et al. 2003).

The concept of diversity can be applied to anything that can be distributed into categories (Margalef 1968). Each cytometrically-defined population contains a group of cells that share a similar set of cytometric properties (size, light scatter, fluorescence), thus the number and relative abundance of these populations can be used to calculate indices of cytometric diversity. The intensities at which a PP cell scatters light and emits fluorescence depend on various factors including its taxonomic affiliation, age (on which size depends), physiological state (on which fluorescence depends), and others. Cytometric diversity refers to categories of PP that do not necessarily correspond to taxonomic identities, and differs from species diversity in that it includes richness in physiological as well as in genetic variation (Li 1997). Few studies, however, have taken advantage of this useful information provided by the flow cytometer to investigate patterns in PP cytometric group diversity. Li (1997) proposed the use of cytometric diversity based on each individual particle and found a tendency for more richness and evenness in marine environments with higher primary production and chl a concentration. While some authors described the dynamics of several PPP populations in a single environment (i.e. Crosbie et al. 2003), a comparison among large number of aquatic environments including the photosynthetic and the heterotrophic fraction of PP using FC has not yet been performed, and most published studies tend to focus either on the HB or on the PPP component alone.

The relatively few studies considering all fractions of PP report that both PPP and HB predominate over larger phytoplankton in oligotrophic systems (Stockner \& Antia 1986, Porter et al. 1988, Cotner \& Biddanda 2002), while the heterotrophic:autotrophic planktonic biomass ratio declines with increasing chl a concentration in lakes (del Giorgio \& Gasol 1995) and in the ocean (Gasol et al. 1997). These studies analyzed patterns of abundance and biomass of the main components of the PP fractions along trophic gradients. There is less information on patterns along latitudinal gradients, and what there is relates to marine environments (e.g. Buck et al. 1996). Relatively little is known about the spatial distribution of different PP populations in freshwater systems along environmental gradients across broad geographic regions and the extent to which environmental factors regulate their dynamics (e.g. Callieri et al. 2007, 2012). In a previous study, we analyzed the bacterioplankton community structure in lakes located along a Patagonian- 
Antarctic gradient using the molecular fingerprinting technique denaturing gradient gel electrophoresis (DGGE), and we observed that both latitude and trophic status of the water bodies influence bacterioplankton abundance and composition (Schiaffino et al. 2011). The aim of the present study was to test whether patterns of PP assessed by FC in the same lakes were also determined by trophic status and latitude. We identified the environmental variables that regulate PP structure along a large latitudinal gradient. We maximized the variability in ecological and trophic regimes among the freshwater bodies analyzed, including as much as possible of the variation in lake size and trophic status existing in the region (deep lakes, shallow lakes and ponds). We hypothesized that PP structure (abundance, cytometric population richness and diversity) is influenced both by latitude and trophic status of the lakes, with PP abundance, cytometric richness and diversity decreasing towards higher latitudes and increasing with increasing trophic status of the water bodies.

\section{MATERIALS AND METHODS}

\section{Study sites}

We studied 32 freshwater bodies in Argentinean Patagonia, in the provinces (from north to south) of Chubut, Santa Cruz, and Tierra del Fuego, located along a latitudinal gradient from $45^{\circ} 22^{\prime}$ to $54^{\circ} 52^{\prime} \mathrm{S}$, representing a distance of $1100 \mathrm{~km}$ (Fig. 1). Different types of water bodies were sampled: deep lakes, shallow lakes and ponds, which differed in morphological and limnological characteristics (Table 1). Determination of the trophic status of the water bodies was based on chl a concentrations taking into account the values proposed by Wetzel (2001).

Following the classification of the Geographical Lake Regions of Argentina by Quirós \& Drago (1999), Patagonian lakes are contained in two regions: the 'Andean Patagonia Region' and the 'Patagonian Plateau Region'. Tierra del Fuego Island contains some lakes that fall within the Andean Patagonian Region, while others are located on the Patagonian Plateau of the island. The deepest lakes are located in Andean Patagonia and Tierra del Fuego. Lakes in Andean Patagonia were mainly formed by glacial and tectonic processes, which, together with hard rock composition and strong fluvial erosion, account for their typically very dilute waters; thus, these lakes are mostly ultraoligotrophic or oligotrophic. This region contains the largest and deepest glacial lakes

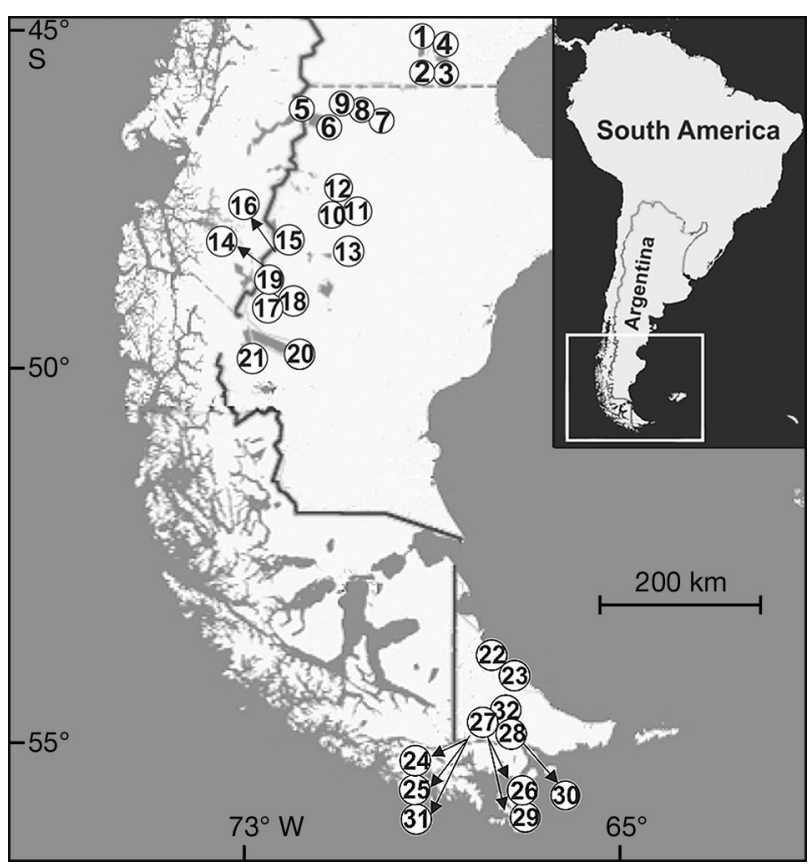

Fig. 1. Locations of water bodies in Patagonia studied to determine picoplankton abundance and cytometric group diversity. Numbers correspond to the water bodies listed and described in Table 1. Arrows indicate water bodies located close together

in South America, situated in glacial valleys (Díaz et al. 2000). The lakes on the Patagonian Plateau are generally shallower than the Andean lakes and range from mesotrophic to eutrophic (Quirós \& Drago 1999), with higher total phosphorus and chl a values (Quirós \& Cuch 1985). Mean annual temperature in Patagonia ranges from $12^{\circ} \mathrm{C}$ in the northeast to $3^{\circ} \mathrm{C}$ towards the south in Tierra del Fuego. From the Andes eastward, total annual precipitation decreases from approximately $2000 \mathrm{~mm}$ to less than $200 \mathrm{~mm}$ $\mathrm{yr}^{-1}$ (Paruelo et al. 1998).

\section{Sampling sites and environmental parameters}

The samples were collected during spring (2007 in Chubut and Santa Cruz, and 2008 in Tierra del Fuego) from the euphotic zone of the water bodies. In deep lakes, integrated samples were collected within the epilimnetic region of the euphotic zone from the surface down to $5 \mathrm{~m}$, whereas in shallow lakes samples were obtained from about $30 \mathrm{~cm}$ below the surface. Temperature, $\mathrm{pH}$ and conductivity were measured in situ with a Horiba D-54 meter, and dissolved oxygen (DO) with a HI 9146 Hanna portable meter. Samples for nutrient and chl a analyses were imme- 
diately filtered through Whatman ${ }^{\circledR}$ GF/F filters. Ammonium and nitrate concentrations were determined using a Hach ${ }^{\mathrm{TM}} \mathrm{DR} / 2800$ spectrophotometer and their corresponding reagent kits (detection limit for all nutrients $0.01 \mathrm{mg} \mathrm{l}^{-1}$ ) on $\mathrm{GF} / \mathrm{F}$ filtrates. Concentrations of chl $a$, corrected for phaeopigments, were determined by spectrophotometry before and after acidification $(\mathrm{HCl} 0.1 \mathrm{~N}$ ). Extractions of pigments from the GF/F filters were carried out in $90 \%$ HPLC grade acetone, with two 15-min sonication steps separated by overnight storage at $4^{\circ} \mathrm{C}$ (Descy et al. 2009). The equations published by Marker et al. (1980) were used for calculations. In situ underwater measurements of photosynthetically active radiation
(PAR) were obtained using a LI-COR radiometer equipped with a submersible spherical quantum sensor (Li-193 SA, Li-Cor PAR). The vertical attenuation coefficient of PAR $\left(K_{\mathrm{d}}\right)$ was calculated as the slope of the relationship between $\ln$-irradiance and depth (Kirk 1994).

\section{Epifluorescence microscopy}

Samples for epifluorescence microscopy were preserved with the addition of filtered $(0.22 \mu \mathrm{m}$ Millipore) cold glutaraldehyde $10 \%$ (1\% final concentration). Fixed samples were filtered through a $0.2 \mu \mathrm{m}$

Table 1. Main morphometric and physicochemical features of 32 Patagonian water bodies studied to determine picoplankton abundance and cytometric group diversity. Numbers in the left hand column refer to the locations shown in Fig. 1. Latitudes and longitudes are expressed in decimal degrees. masl: meters above sea level; conduct.: Conductivity; DO: dissolved oxygen; DIN: dissolved inorganic nitrogen; $K_{d}$ vertical photosynthetically active radiation (PAR) attenuation coefficient; Chl a: chlorophyll a; L: deep lake; P: pond; SL: shallow lake; O: oligotrophic; M: mesotrophic; E: eutrophic; na: data not available

\begin{tabular}{|c|c|c|c|c|c|c|c|c|c|c|c|c|c|}
\hline $\begin{array}{l}\text { No./ } \\
\text { Prov }\end{array}$ & nce & $\begin{array}{l}\text { Trophic } \\
\text { status }\end{array}$ & $\begin{array}{l}\text { Lat. } \\
\left({ }^{\circ} \mathrm{S}\right)\end{array}$ & $\begin{array}{l}\text { Long. } \\
\left({ }^{\circ} \mathrm{W}\right)\end{array}$ & $\begin{array}{l}\text { Altitude } \\
\text { (masl) }\end{array}$ & $\begin{array}{l}\text { Area } \\
\left(\mathrm{km}^{2}\right)\end{array}$ & $\begin{array}{c}\text { Temp. } \\
\left({ }^{\circ} \mathrm{C}\right)\end{array}$ & $\mathrm{pH}$ & $\begin{array}{l}\text { Conduct. } \\
\left(\mu \mathrm{S} \mathrm{cm}^{-1}\right)\end{array}$ & $\begin{array}{c}\mathrm{DO} \\
\left(\mathrm{mg} \mathrm{l}^{-1}\right)\end{array}$ & $\begin{array}{c}\text { DIN } \\
\left(\mathrm{mg} \mathrm{l}^{-1}\right)\end{array}$ & $\begin{array}{c}K_{\mathrm{d}} \\
\left(\mathrm{m}^{-1}\right)\end{array}$ & $\begin{array}{l}\text { Chl } a \\
\left(\mu \mathrm{g} \mathrm{l}^{-1}\right)\end{array}$ \\
\hline \multicolumn{14}{|c|}{ Chubut } \\
\hline 1 & L. Musters & M & 45.55 & 69.14 & 277 & 438.506 & 12.6 & 7.8 & 310 & 9.3 & 0.23 & 1.15 & 2.62 \\
\hline 2 & P.2 & M & 45.57 & 69.11 & 297 & 0.043 & 15.5 & 8.4 & 490 & 10.5 & 0.41 & 2.54 & 4.75 \\
\hline 3 & P.3 & M & 45.60 & 69.00 & 269 & 0.002 & 14.1 & 8.1 & 110 & 10.9 & 0.42 & 2.27 & 9.68 \\
\hline 4 & L. Colhué Huapi & $\mathrm{E}$ & 45.37 & 68.95 & 280 & 762.559 & 10.0 & 8.7 & 1350 & 9.3 & 0.28 & 28.52 & 47.01 \\
\hline \multicolumn{14}{|c|}{ Santa Cruz } \\
\hline 5 & L. Pueyrredón & $\mathrm{O}$ & 47.38 & 71.97 & 158 & 308.884 & 8.9 & 7.3 & 130 & 11.8 & 0.07 & 0.19 & 0.41 \\
\hline 6 & L. Posadas & $\mathrm{O}$ & 47.45 & 71.81 & 160 & 39.877 & 10.0 & 7.8 & 210 & 9.8 & 0.05 & 0.09 & 0.38 \\
\hline 7 & P.7 & $\mathrm{E}$ & 47.34 & 70.99 & 447 & 0.001 & 27.0 & 8.3 & 1810 & 8.1 & na & 1.17 & 17.02 \\
\hline 8 & L. Ghio & M & 47.27 & 71.51 & 400 & 59.464 & 12.8 & 8.2 & 4760 & 10.3 & na & 0.34 & 0.11 \\
\hline 9 & P.9 & $\mathrm{E}$ & 47.20 & 71.60 & 580 & 0.024 & 20.7 & 8.2 & 4110 & 13.9 & 0.05 & 3.42 & 18.35 \\
\hline 10 & P.11 & $\mathrm{E}$ & 48.69 & 71.15 & 830 & 0.015 & 10.1 & 8.2 & 560 & 9.2 & 0.06 & 7.04 & 19.56 \\
\hline 11 & P.12 & M & 48.68 & 71.13 & 848 & 0.092 & 13.6 & 8.2 & 4600 & 9.0 & 0.03 & 1.70 & 5.43 \\
\hline 12 & P.13 & $\mathrm{E}$ & 48.63 & 71.14 & 880 & 0.005 & 17.3 & 8.3 & 230 & 9.3 & 0.18 & na & 36.67 \\
\hline 13 & L. Cardiel & M & 48.99 & 71.13 & 280 & 350.681 & 11.0 & 9.3 & 4360 & 10.3 & 0.10 & 0.23 & 0.76 \\
\hline 14 & P.15 & $\mathrm{O}$ & 49.26 & 72.89 & 425 & 0.005 & 7.3 & 7.3 & 80 & 11.9 & 0.16 & 0.49 & 1.78 \\
\hline 15 & L. del Desierto & $\mathrm{O}$ & 49.08 & 72.89 & 506 & 9.273 & 8.2 & 6.9 & 20 & 11.9 & 0.14 & 0.12 & 0.20 \\
\hline 16 & P.17 & $\mathrm{O}$ & 49.13 & 72.93 & 459 & 0.004 & 14.8 & 7.0 & 50 & 9.5 & 0.17 & 0.61 & 0.29 \\
\hline 17 & P.18 & M & 49.59 & 72.30 & 253 & 0.185 & 12.3 & 8.2 & 380 & 10.3 & 0.34 & 0.42 & 3.87 \\
\hline 18 & P.19 & M & 49.59 & 72.31 & 253 & 0.076 & 13.6 & 8.3 & 560 & 11.3 & 0.17 & 0.54 & 3.17 \\
\hline 19 & L. Viedma & $\mathrm{O}$ & 49.39 & 72.87 & 273 & 1219.19 & 8.3 & 6.7 & 40 & 11.4 & 0.04 & 1.62 & 1.02 \\
\hline 20 & L. Argentino & $\mathrm{O}$ & 50.31 & 72.80 & 181 & 1419.48 & 10.0 & 6.9 & 40 & 9.3 & 0.17 & 1.31 & 0.17 \\
\hline 21 & P. 22 & M & 50.32 & 72.79 & 184 & 0.995 & 12.3 & 8.1 & 610 & 10.5 & 0.07 & 3.06 & 8.00 \\
\hline \multicolumn{14}{|c|}{ Tierra del Fuego } \\
\hline 22 & SL. de Los Cisnes & M & 53.79 & 67.78 & 8 & 3.116 & 12.7 & 9.0 & 25800 & 12.0 & 0.13 & 2.73 & 0.41 \\
\hline 23 & SL. San Luis & M & 53.92 & 67.60 & 10 & 3.748 & 10.7 & 8.1 & 313 & 10.7 & 0.08 & 2.06 & 0.68 \\
\hline 24 & L. Acigami & $\mathrm{O}$ & 54.83 & 68.56 & 20 & 19.197 & 4.5 & 7.6 & 78 & 11.2 & 0.08 & 1.50 & 0.12 \\
\hline 25 & SL. Laguna Negra & $\mathrm{O}$ & 54.84 & 68.59 & 29 & 0.138 & 6.1 & 6.9 & 66 & 10.1 & 0.13 & 0.80 & 0.41 \\
\hline 26 & L. Escondido & $\mathrm{O}$ & 54.68 & 67.81 & 120 & 6.054 & 4.5 & 7.4 & 103 & 11.5 & 0.07 & 0.64 & 0.10 \\
\hline 27 & L. Fagnano & $\mathrm{O}$ & 54.59 & 67.62 & 27 & 646.691 & 6.7 & 7.6 & 85 & 11.7 & 0.07 & 0.69 & 0.10 \\
\hline 28 & P. 27 & M & 54.60 & 67.63 & 43 & 0.0003 & 8.3 & 6.5 & 205 & 7.7 & 0.08 & 3.30 & 0.34 \\
\hline 29 & SL. Victoria & $\mathrm{O}$ & 54.78 & 67.70 & 103 & 0.091 & 7.2 & 7.4 & 55 & 11.0 & 0.06 & 1.77 & 0.51 \\
\hline 30 & P. 29 & M & 54.87 & 67.35 & 11 & 0.139 & 8.2 & 7.9 & 110 & 10.7 & 0.04 & 2.98 & 0.29 \\
\hline 31 & SL. Verde & $\mathrm{O}$ & 54.85 & 68.58 & 15 & 0.001 & 13.4 & 8.1 & 1284 & 10.5 & 0.08 & 2.16 & 0.31 \\
\hline 32 & L. Yehuin & $\mathrm{O}$ & 54.36 & 67.78 & 50 & 42.482 & 8.0 & 8.0 & 197 & 11.5 & 0.14 & 0.41 & 0.10 \\
\hline
\end{tabular}


pore-size polycarbonate black filter, and cells were stained with DAPI $(4$ ', 6-diamidino-2-phenylindole; $10 \mu \mathrm{g} \mathrm{ml}^{-1}$ final concentration), following the procedure outlined by Porter \& Feig (1980). The samples were stored at $-20^{\circ} \mathrm{C}$ until analysis in the laboratory. Total HB, Pcy and Peuk abundances were determined by epifluorescence using an Olympus BX40F4 microscope at $1000 \times$ magnification. Bacterioplankton counts were performed using UV excitation (archaea would also be included in these counts), and Pcy and Peuk observations were done using both blue and green-wavelength excitation. Under blue light excitation (450 to $490 \mathrm{~nm}$ ), Peuk appeared red, due to chl $a$ autofluorescence, whereas PE-rich Pcy fluoresced yellow and PC-rich Pcy dark red. Under green light excitation $(546 \mathrm{~nm})$, PE-rich cells produced yellow/orange emissions and PC-rich cells generated red emissions.

\section{Flow cytometry}

Samples $(4 \mathrm{ml})$ were fixed with cold glutaraldehyde $10 \%$ ( $1 \%$ final concentration), left in the dark for $10 \mathrm{~min}$ at room temperature, frozen in liquid nitrogen and then stored at $-80^{\circ} \mathrm{C}$. Two subsamples were taken for separate counts of HB and PPP. For HB determination, a DMSO-diluted Syto 13 (Molecular Probes) stock (10:1) at $2.5 \mu \mathrm{mol} \mathrm{l}^{-1}$ final concentration was added to $400 \mu \mathrm{l}$ of sample, left for about 10 min in the dark to complete the nucleic acid (NA) staining, and run in the flow cytometer. We used a FACSCalibur (Becton Dickinson) flow cytometer equipped with a standard $15 \mathrm{~mW}$ blue argon-ion (488 $\mathrm{nm}$ emission) laser and a red laser diode $(635 \mathrm{~nm})$. At least 100000 events were acquired for each sample. Fluorescent beads $(1 \mu \mathrm{m}$, Fluoresbrite carboxylate microspheres [Polysciences]) were added at a known density as internal standards. The bead standard concentration was determined by epifluorescence microscopy. FC allowed separation and quantification of at least $2 \mathrm{HB}$ populations or fractions: high nucleic-acid content (HNA) and low nucleic-acid content (LNA) bacterioplankton, that can be detected by their signature in plots of side scatter light (SSC) versus green fluorescence of NAbound stains (FL1) (e.g. Gasol et al. 1999, Bouvier et al. 2007). Often, more than one HB population was identified and quantified within either the HNA or the LNA. For PPP, we used the same procedure as for $\mathrm{HB}$, but without addition of stain. Small algae were easily identified in plots of SSC versus blue laserdependent red fluorescence (FL3), orange fluores- cence (FL2) versus FL3, and red laser-dependent farred fluorescence (FL4) versus FL3 (Olson et al. 1993). Data analysis was performed with the CellQuest software (Becton Dickinson). HB of one water body, Lake Colhué Huapi, could not be counted due to inorganic particle noise interference in the cytograms.

For any potential differences in the measurement conditions, the relative intensity $(\mathrm{P})$ of each parameter $X$ (i.e. SSC, FL1, FL2 and FL3) for each different population identified (i) was standardized by dividing the $\log _{10}$ transformed mean value by that of the standard bead population (b): $\mathrm{P}_{X}=\log _{10} X_{i} / \log _{10} X_{b}$.

\section{Statistical analyses}

Correlations between variables were carried out using Spearman's rho tests. These and the linear regression analyses were performed using SPSS 15.0.1 (StatSoft). Variability in the abundances of PP among groups of water bodies was identified using 1-way ANOVA and Tukey-Kramer means post-hoc comparison tests $(\alpha=0.05)$. The Tukey-Kramer test was chosen because of its conservative nature when sample sizes for each category are unequal, as they were in this case. Most variables for statistical tests were $\log _{10}$-transformed to correct deviations from normality and homoscedasticity, which were controlled respectively with Kolmogorov-Smirnov and Levene's tests $(\alpha=0.01)$.

Environmental gradients and the relevance of the environmental variables were explored using principal components analysis (PCA) (ter Braak \& Smilauer 2002). To identify the environmental factors controlling PP abundances, we performed a redundancy analysis (RDA) with a quantitative community matrix constructed from the total abundance of each fraction identified by FC (LNA, HNA, PE-rich Pcy, PC-rich Pcy and Peuk). RDA was used because a detrended correspondence analysis performed with the quantitative community matrix indicated that PP abundances showed a linear response (ter Braak \& Smilauer 2002). Multivariate analyses were performed with the software CANOCO (ter Braak 1991). Forward selection was used for adding environmental variables to the models and those variables strongly correlated were eliminated from the analyses as they provided redundant information. Significance of the canonical axes was assessed using Monte Carlo permutation tests $(\alpha=0.05)$. The PP abundance matrix was first transformed to natural logarithms $\left(y^{\prime}=\ln (y+1)\right.$; Berthet \& Gérard 1965, ter Braak 1987). 


\section{Definition of cytometric populations and estimation of cytometric diversity}

We used the term 'cytometric populations' or 'cytometric group' to name a group of cells that show a similar set of cytometric properties (size, light scatter, fluorescence) and can be seen to associate in the FC plots. PP can be split into non-phototrophic bacterioplankton (HB to simplify, although archaea and chemoautotrophic bacteria are surely included) and PPP. HB can be divided at least into HNA and LNA, but as explained below, these can be split further in many more categories, based on their appearance in an SSC-NA fluorescence plot. Similarly, PPP contains eukaryotic (Peuk) and prokaryotic (Pcy) components, and these can be further separated into PE-rich Pcy and PC-rich Pcy. These distinctions allowed us to create, evaluate and use certain ratios (e.g. HB:PPP, HNA:LNA, Peuk:Pcy, PE-rich Pcy:PC-rich Pcy) as indicators of global PP structure. Furthermore, within each of the groups (HNA, LNA, PPP, etc.), there were often several populations that could be singularized in an FC plot. The number and relative abundance of these populations was used to calculate indices of 'cytometric group diversity'. A final step, not used in this work, would be to extract cytometric diversity measurements from the individual, particle-by-particle, flow cytometric analyses (e.g. Li 1997).

As defined by their cytometric characteristics, similar PP populations (those populations detected within HB, PE-rich Pcy, PC-rich Pcy and Peuk) might appear in different lakes. To objectively determine which populations could be considered to be likely the same ones, we classified all detected populations by cluster analysis of a quantitative matrix using the different flow cytometer signals (SSC, FL1, FL2 and FL3) after standardization to the reference bead characteristics. We used the hierarchical clustering and the Ward's minimum variance method in software XL Stat (Addinsoft SARL). This analysis allowed the identification of cytometric populations with similar cytometric parameters and that appeared in more than one water body. Those that were $<60 \%$ different were considered to be the same population in different lakes. A total of $28 \mathrm{HB}$, 14 PE-rich Pcy, 8 PC-rich Pcy and 41 Peuk unique cytometric populations were defined. It is worth mentioning that each cytometric population does not necessarily correspond to a single species, and that the same organism can have different cytometric signatures in different lakes depending, for example, on the light climate in which it thrives (see e.g. Fig. 10 in Stenuite et al. 2009).
We then built another quantitative matrix using the abundances of each identified PP population that was tested against a second matrix obtained from environmental data using a canonical correspondence analysis (CCA), with the purpose of identifying the environmental factors controlling PP cytometric population composition and abundance. CCA was used because a detrended correspondence analysis of the PP population abundance matrix determined that the gradient length along the first ordination axis was $>4$ SD (ter Braak \& Smilauer 2002). To further explore the patterns in PP cytometric population abundances, we used the canonical variation partitioning procedure (Borcard et al. 1992). This type of analysis allows the discrimination of patterns related to one set of explanatory variables while controlling for a second set of explanatory variables (Legendre \& Legendre 1998) and it is useful to measure the relative importance of non-spatial environmental factors (physics, chemistry, morphometry) versus spatial factors (geographic coordinates) in biogeographic studies (Cottenie 2005, Langenheder \& Ragnarsson 2007). A partial CCA (pCCA) was carried out with the PP cytometric population abundance matrix and the spatial matrix (latitude and longitude) while controlling for the effect of non-spatial environmental descriptors (chl $a, \mathrm{pH}$ and DO), and with the PP population abundance matrix and the non-spatial environmental data set while controlling for the effects of the spatial matrix. Calculations were performed with software CANOCO (ter Braak 1991) and the community abundance matrix was first transformed to natural logarithms (Berthet \& Gérard 1965, ter Braak 1987).

Cytometric group diversity was calculated for HB and for PPP separately based on the relative abundance of each cytometrically-derived group, using the reciprocal Simpson's diversity index $(D)=1 / \Sigma$ $\left(n_{i} / N\right)^{2}$, where $n_{i}$ is the abundance of each population identified (i) and $N$ is the total abundance of all populations identified in each sample.

\section{RESULTS}

\section{Characteristics of the water bodies}

The studied water bodies covered a wide range of trophic states, from oligotrophic to eutrophic, and presented a great variety of morphometric characteristics, from large deep lakes to small shallow ponds. We considered chl $a$ as the best descriptor of their trophic status, with values ranging from 0.1 to $47.0 \mu \mathrm{g} \mathrm{l}^{-1}$. Dissolved inorganic nitrogen (DIN $=$ nitrate + ammonium $)$ 
ranged from 0.03 to $0.42 \mathrm{mg} \mathrm{l}^{-1}$. In addition, water temperatures varied considerably among the water bodies, ranging from 4.5 to $27^{\circ} \mathrm{C}$ (Table 1) even though they were all sampled in springtime. Water temperature was negatively correlated to latitude $(\mathrm{r}=-0.60, \mathrm{p}<0.0001, \mathrm{~N}=$ 32 ) and positively correlated to $\mathrm{chl} a$ $(\mathrm{r}=0.58, \mathrm{p}<0.0001, \mathrm{~N}=32)$.

The freshwater environments are located along 2 major gradients. The latitudinal gradient from northern (Chubut) to southern Patagonia (Tierra del Fuego) corresponds to a gradient from higher to lower temperatures and trophic status. The east-west gradient, i.e. from Andean Patagonia (west) to Plateau Patagonia (east) also corresponds to a gradient in the trophic status of the lakes, since most Andean water bodies are oligotrophic, deep and transparent and most Plateau water bodies are meso-eutrophic and relatively shallow; it is also a conductivity gradient, as most large lakes are diluted while the shallow lakes are less diluted. These 2 gradients are evidenced in the results of the PCA using the environmental data alone (Fig. 2). The first 2 axes, accounting for $51.7 \%$ of the variance (Axis 1: $32.2 \%$, Axis 2: $19.5 \%$ ), can be interpreted as follows: the first axis was mainly defined by chl $a$, light attenuation $\left(K_{\mathrm{d}}\right), \mathrm{DIN}, \mathrm{pH}$ and DO (intraset correlation coefficients: $0.86,0.74,0.55,0.49$ and -0.34 , respectively) as well as latitude (correlation coefficient: -0.74 ), whereas the second axis was mainly correlated to longitude, latitude, lake area and $\mathrm{pH}$ (intraset correlation coefficients $0.85,-0.50,0.47$ and -0.46 , respectively). The fact that $K_{\mathrm{d}}$ correlates mainly with chl $a(\mathrm{r}=0.49, \mathrm{p}<$ $0.001, N=32$ ) indicates that, in these lakes, the vertical attenuation coefficient is basically determined by the biomass of phototrophs, rather than by landscape processes that bring color. An ordination of the lakes (Fig. 2) identified 3 areas with contrasting characteristics: (1) Plateau water bodies, generally small, with higher $\mathrm{pH}$ and conductivity (both variables highly correlated $\mathrm{r}=0.86, \mathrm{p}<0.0001, \mathrm{~N}=32$ ), DIN, $K_{\mathrm{d}}$ and chl $a_{i}(2)$ Andean water bodies, generally larger, more diluted, with lower $\mathrm{pH}$ and chl $\mathrm{a}$ and higher DO values; and (3) Tierra del Fuego water bodies, at higher latitudes, with lower temperatures, DIN and chl $a$.

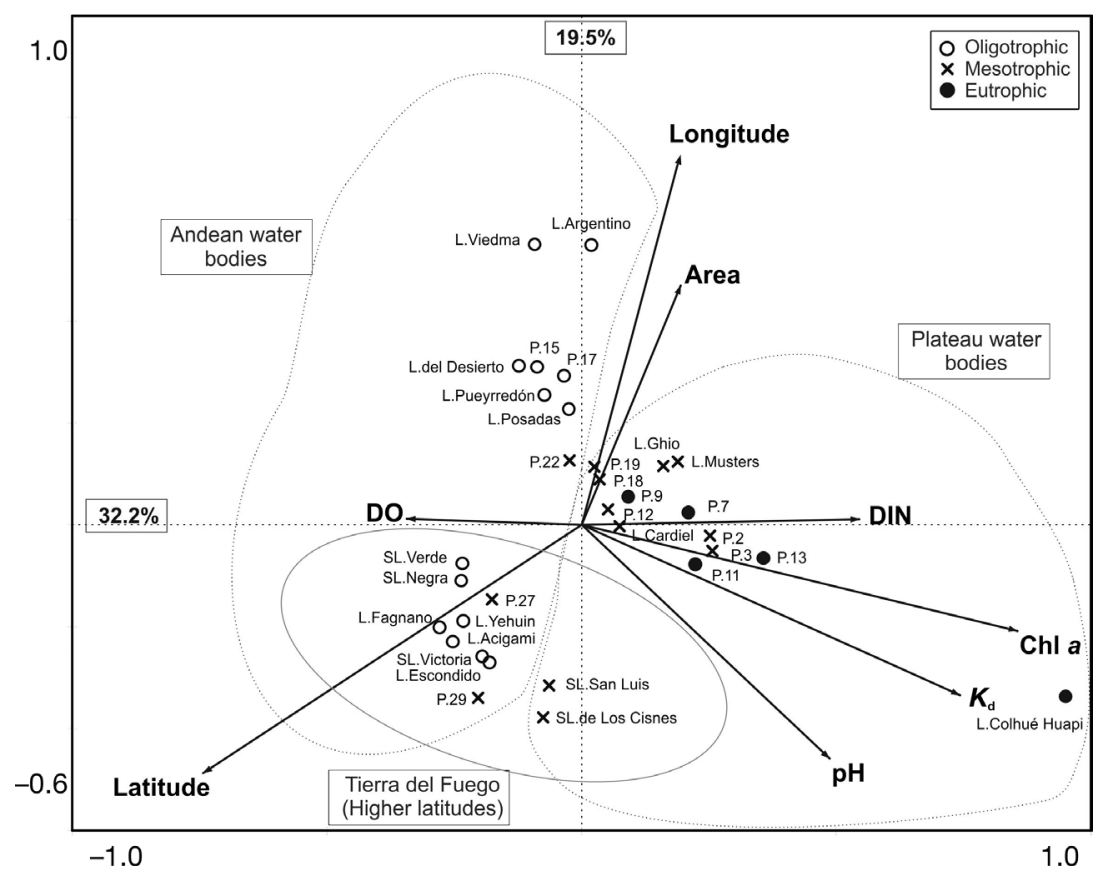

Fig. 2. Principal components analysis (PCA) showing the ordination of oligotrophic, mesotrophic and eutrophic water bodies in 3 lake regions of Patagonia (Andean, Plateau and Tierra del Fuego; see Table 1 for water body identificariables analyzed were $\mathrm{pH}$, dissolved oxygen (DO), dissolved inorganic nitrogen (DIN), chlorophyll a (chl a), vertical PAR attenuation coefficient $\left(K_{\mathrm{d}}\right)$ and lake area; geographic variables were latitude and lonare the percent variance explained by each axis

\section{Validating flow cytometry abundances}

The data used in our analyses was obtained by FC, but we contrasted the values with those obtained by epifluorescence microscopy. The abundances obtained by both techniques (epifluorescence and FC) were quite similar, well correlated (Spearman's rho $\mathrm{r}=0.80$ to 0.87 , with $\mathrm{N}=32$ to 31 , all $\mathrm{p}<0.0001$ ), with data points around the 1:1 line (log-log slopes not significantly different from 1 , and ordinates not significantly different from $0, p>0.05$ ). In addition, we observed the presence of both PE-rich and PC-rich Pcy after blue and red-light excitation under epifluorescence microscopy, an observation that was replicated using FC, with which we detected orange signals after excitation with a blue laser (PE), and far-red signals after excitation with a red laser (PC).

\section{Heterotrophic bacterioplankton}

Initially, we analyzed $\mathrm{HB}$ as divided into 2 major fractions, HNA and LNA. In terms of abundance, LNA, HNA and total HB were significantly higher in 
mesotrophic and eutrophic water bodies than in oligotrophic ones (Table 2), and were positively correlated to chl a concentration (Fig. 3a) and $\mathrm{pH}(\mathrm{r}=0.71$ and $\mathrm{r}=0.65$ for LNA and HNA, respectively; both $\mathrm{p}<$ 0.0001); whereas HB abundances were negatively related to latitude (Fig. 3b) and positively related to water temperature (Fig. 3c). As expected, the eutrophic lakes had higher abundances of all types of bacteria, followed by the mesotrophic and then the oligotrophic lakes. In terms of lake position (Fig 2), the Plateau water bodies had higher abundances of all types of bacteria than the other 2 areas, which were not distinguishable. The ratio of HNA to LNA bacteria (or the \%HNA) was not related to any of the variables studied, and did not vary systematically among any of the water body groups analyzed.

\section{Photosynthetic picoplankton}

The abundance of total PPP was significantly higher in eutrophic water bodies than in oligotrophic lakes (Table 3). PPP abundance showed a positive and significant relationship with $\mathrm{pH}(\mathrm{r}=0.61, \mathrm{p}<0.001)$ and increased but not significantly with chl a concentration (Fig. 4a). A negative, significant relationship was found with latitude (Fig. $4 \mathrm{~b}$ ), whereas water temperature did not correlate with PPP abundance (Fig. 4c).

We observed different cytometrically-defined populations within the PPP, which we classified into the 3 groups PE-rich Pcy, PC-rich Pcy and Peuk (i.e. PP with chl $a$, but not PC or PE). All the water bodies harbored Peuk cells, but not all of them had Pcy. In $9.2 \%$ of the water bodies Pcy were not found, in $50 \%$ of the environments only PE-rich cells were present,

Table 2. Abundances (cells $\mathrm{ml}^{-1}$ ) of low nucleic-acid content bacterioplankton (LNA), high nucleic-acid content bacterioplankton (HNA) and all heterotrophic bacterioplankton (HB) determined by flow cytometry in oligotrophic, mesotrophic and eutrophic water bodies. Ranges represent maximum and minimum values, and means are given in parentheses. One-way ANOVA tests and post-hoc TukeyKramer tests were used to identify significant differences. Means in the same column followed by different letter ( $a$ or $b$ ) are significantly different at $\mathrm{p}<0.05$ (Tukey-Kramer's test for unequal N)

\begin{tabular}{|lccc|}
\hline Trophic status & LNA & HNA & All HB \\
\hline Oligotrophic & $1.1 \times 10^{5}-2.4 \times 10^{6}$ & $5.5 \times 10^{4}-2.7 \times 10^{6}$ & $1.8 \times 10^{5}-5.1 \times 10^{6}$ \\
$(\mathrm{~N}=14)$ & $\left(7.2 \times 10^{5}\right) b$ & $\left(5.4 \times 10^{5}\right) b$ & $\left(1.3 \times 10^{6}\right) b$ \\
Mesotrophic & $1.8 \times 10^{6}-9.5 \times 10^{6}$ & $1.1 \times 10^{6}-5.8 \times 10^{6}$ & $3.3 \times 10^{6}-1.2 \times 10^{7}$ \\
$(\mathrm{~N}=13)$ & $\left(3.9 \times 10^{6}\right) a$ & $\left(2.8 \times 10^{6}\right) a$ & $\left(6.6 \times 10^{6}\right) a$ \\
Eutrophic & $5.8 \times 10^{6}-1.5 \times 10^{7}$ & $1.6 \times 10^{6}-1.4 \times 10^{7}$ & $1.0 \times 10^{7}-2.9 \times 10^{7}$ \\
$(\mathrm{~N}=4)$ & $\left(1.0 \times 10^{7}\right) a$ & $\left(6.7 \times 10^{6}\right) a$ & $\left(1.7 \times 10^{7}\right) a$ \\
F-value & 43.139 & 28.566 & 44.650 \\
p-value & $<0.005$ & $<0.005$ & $<0.005$ \\
\hline
\end{tabular}

in $12.5 \%$ only PC-rich cells were found, and in $28.1 \%$ of the water bodies both types of Pcy were present.

The Pcy populations were identified based on their pigment signal, in FL3-FL2 or FL3-FL4 plots for PErich or PC-rich cells, respectively. Noticeably, in 15 out of 32 lakes these Pcy populations showed a large variation in SSC signal: up to 3 orders of magnitude within a single population (Fig. 5). Each one of these Pcy-populations was divided into High-SSC and Low-SSC (similar to the Pcy-A and Pcy-B types defined by Crosbie et al. 2003). Since this increase in SSC was not paralleled by an increase in fluorescence, we believe that these particles were not microcolonies (see 'Discussion'). We found that the percentage of High-SSC Pcy was significantly correlated to chl a concentration $(\mathrm{r}=0.62, \mathrm{p}<0.05, \mathrm{~N}=15)$ and to $K_{\mathrm{d}}(\mathrm{r}=0.49, \mathrm{p}<0.05, \mathrm{~N}=15)$.

The abundance of Peuk increased with increasing trophic status of the lake, being significantly higher in mesotrophic and eutrophic water bodies than in oligotrophic lakes (Table 3). Peuk abundance also correlated positively to $\mathrm{pH}, K_{\mathrm{d}}$ and chl $a(\mathrm{r}=0.61, \mathrm{p}<0.001$; $\mathrm{r}=0.39, \mathrm{p}<0.05$; and $\mathrm{r}=0.62, \mathrm{p}<0.001$, respectively), as well as with total HB abundance ( $\mathrm{r}=0.75, \mathrm{p}<$ 0.0001). The abundance of PE-rich Pcy did not change with the trophic status of the lakes, although the abundance of PC-rich Pcy was significantly higher in eutrophic rather than in oligotrophic water bodies (Table 3). PC-rich cells correlated positively to chl a (r $=0.47, \mathrm{p}<0.01)$, as well as with total HB abundance $(\mathrm{r}$ $=0.54, \mathrm{p}<0.001)$. Consequently, the ratios between PE-Pcy:total Pcy, PE-Pcy:Peuk and Pcy:Peuk were negatively related to $\mathrm{chl} a(\mathrm{r}=-0.60, \mathrm{p}<0.001 ; \mathrm{r}=$ $-0.48, \mathrm{p}<0.01 ; \mathrm{r}=-0.43, \mathrm{p}<0.05$, respectively), whereas the opposite trend was observed for the contribution of PC-Pcy to total Pcy (ratio PC-Pcy:total Pcy, r $=0.56, \mathrm{p}<$ 0.01). The ratios Pcy:Peuk and PEPcy:Peuk were also negatively related to $K_{\mathrm{d}}(\mathrm{r}=-0.41$ and $\mathrm{r}=-0.38$, respectively; both $\mathrm{p}<0.05$ ).

\section{Heterotrophic and photosynthetic picoplankton abundances along environmental gradients}

The result of the RDA analysis using the total abundance of each PP fraction (LNA, HNA, PE-rich Pcy, PC-rich Pcy and Peuk) and the environmental variables is shown in Fig. 6. The first 2 axes accounted 
for $95.8 \%$ of the variance (Axis 1: 82.3, Axis 2: $13.5 \%$ ). The environmental variables were significantly correlated to the first axis $(p=0.002)$ and all canonical axes $(p=0.002)$. The first axis was mainly defined by $\mathrm{pH}$ and chl a (intraset correlation coefficients: 0.62 and 0.61 , respectively); the second axis was mainly correlated to $K_{\mathrm{d}}$ and latitude (intraset correlation coefficients: 0.30 and -0.29 respectively). This analysis
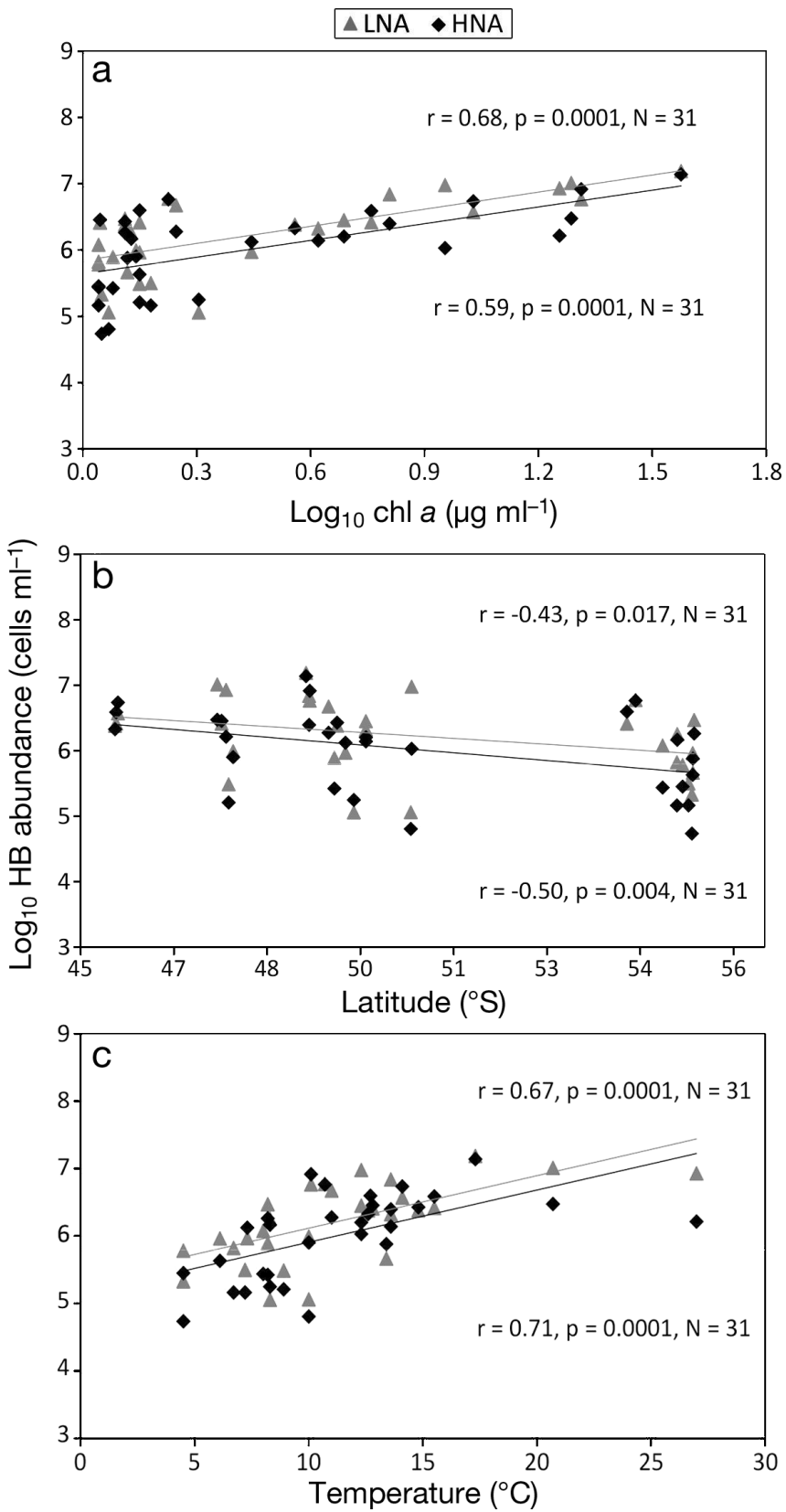

Fig. 3. Relationship (Spearman's rho correlation) between the abundance of heterotrophic bacterioplankton (HB) and (a) chl $a$, (b) latitude, and (c) temperature in Patagonian water bodies. LNA: low nucleic-acid content bacterioplankton; HNA: high nucleic-acid content bacterioplankton shows the importance of trophic status in shaping PP abundances. PC-rich Pcy, Peuk and HB (both HNA and LNA) were plotted on the right side of the graph together with the water bodies located in the Patagonian Plateau and with higher values of $\mathrm{pH}$ and $\mathrm{chl} a_{\text {, }}$ whereas PE-rich Pcy were situated on the left side of the figure together with the Andean water bodies and towards lower values of trophic status variables and
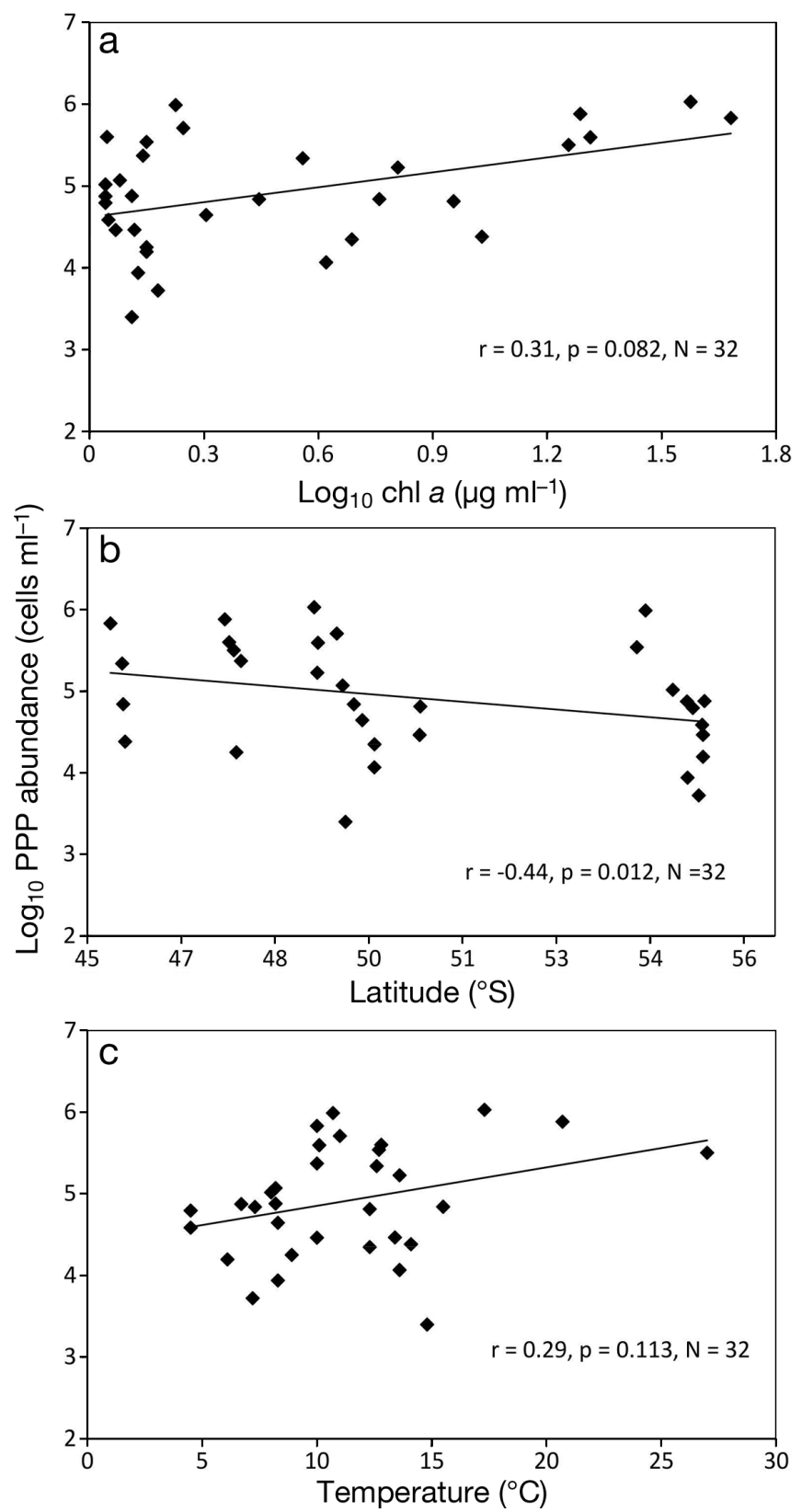

Fig. 4. Relationship (Spearman's rho correlation) between the abundance of photosynthetic picoplankton (PPP) and (a) chl $a$, (b) latitude, and (c) temperature in Patagonian water bodies 
240

Aqua Microbe Ecol 68: 231-250, 2013
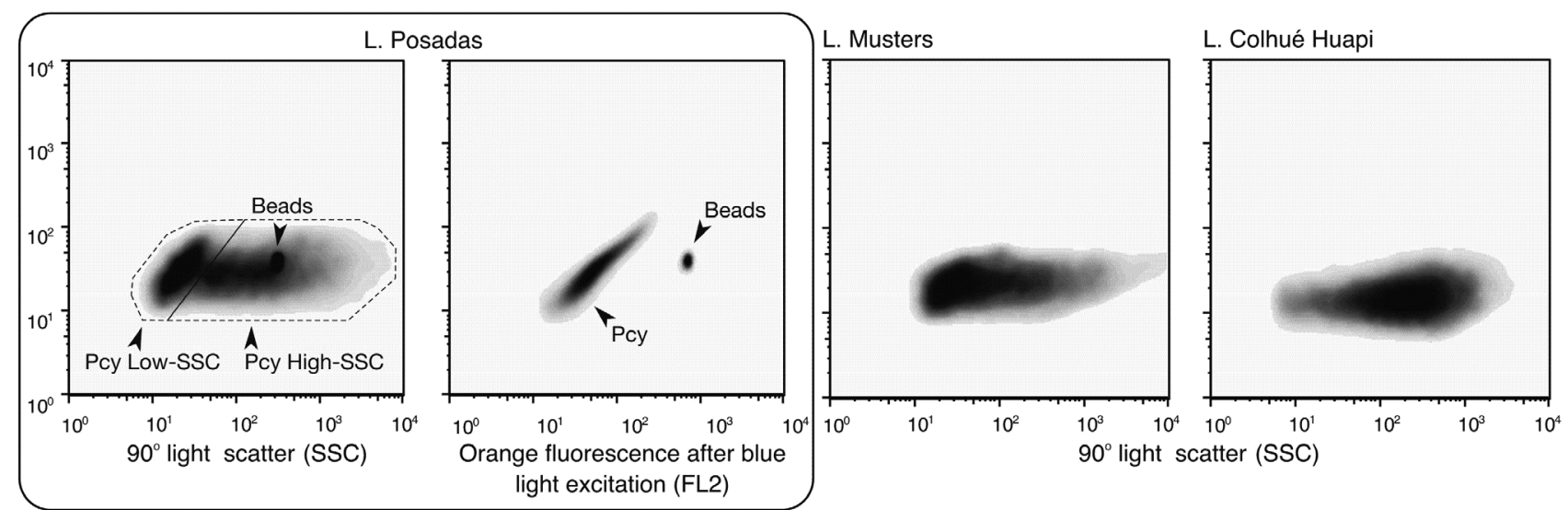

light excitation (FL2)
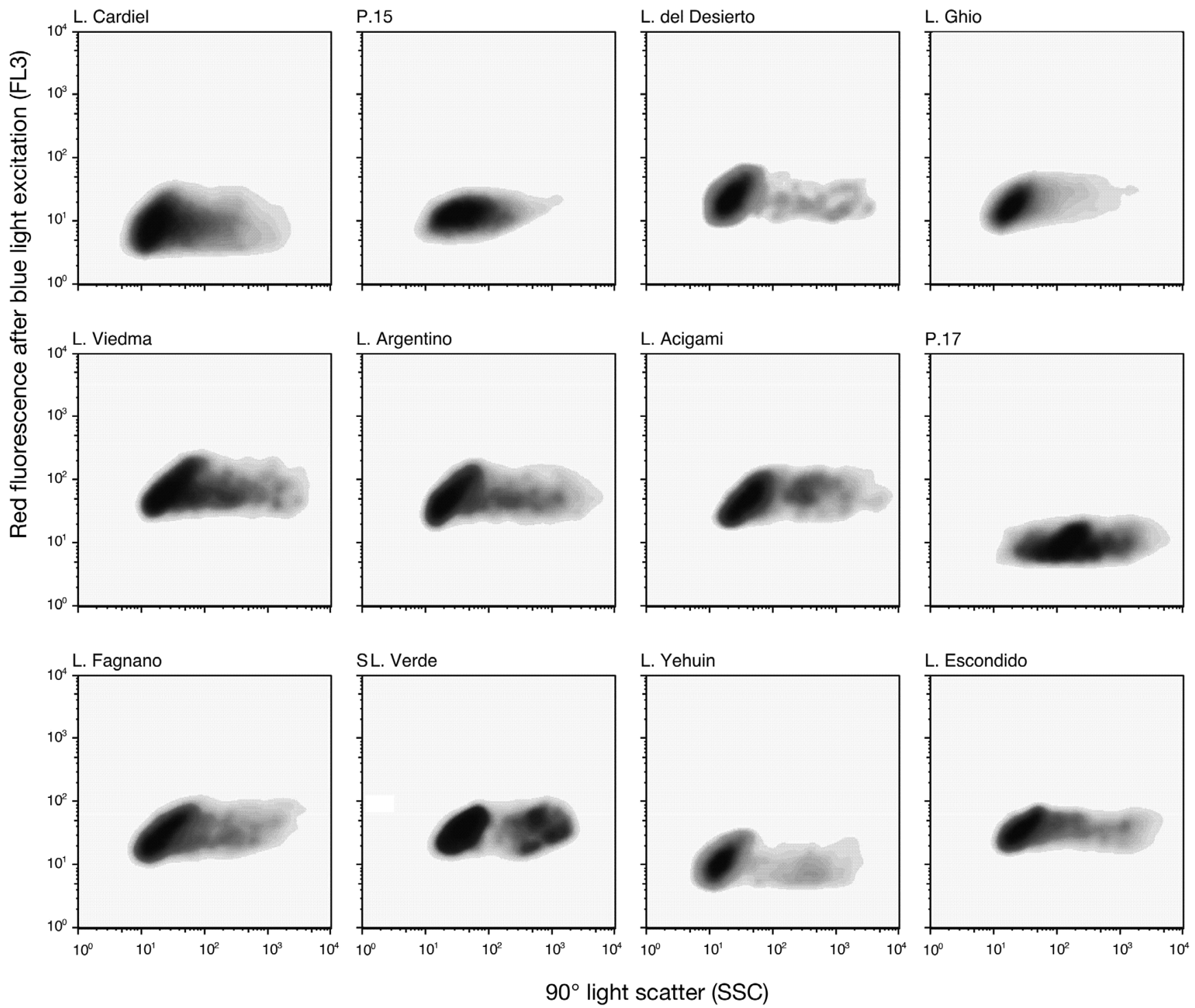

Fig. 5. Cytograms of Patagonian water bodies (lakes and ponds) containing picocyanobacteria (Pry) populations with large variation in side-scatter (SSC) values. Positions of beads and Low-SSC and High-SSC Pry groups are shown for Lake Posadas. For other lakes, only Icy populations are shown, while noise, beads and other photosynthetic picoplankton populations were removed. See Table 1 for water body identifications 
Table 3. Abundances (cells $\mathrm{ml}^{-1}$ ) of phycoerythrin (PE)-rich and phycocyanin (PC)-rich picocyanobacteria, picoeukaryotes (Peuk) and all photosynthetic picoplankton (PPP) cells determined by flow cytometry in oligotrophic, mesotrophic and eutrophic water bodies. Ranges represent maximum and minimum values and means are expressed in parentheses. One-way ANOVA tests and post-hoc Tukey-Kramer tests were used to identify significant differences. Means in the same column followed by different letter ( $a$ and/or $b$ ) are significantly different at $\mathrm{p}<0.05$ (Tukey-Kramer's test for unequal $\mathrm{N}$ )

\begin{tabular}{|lcccc|}
\hline Trophic status & PE-rich & PC-rich & Peuk & PPP \\
\hline Oligotrophic & $0-2.3 \times 10^{5}$ & $0-5.5 \times 10^{4}$ & $3.4 \times 10^{2}-1.6 \times 10^{4}$ & $2.5 \times 10^{3}-2.3 \times 10^{5}$ \\
(N=14) & $\left(5.2 \times 10^{4}\right) a$ & $\left(4.0 \times 10^{3}\right) b$ & $\left(4.2 \times 10^{3}\right) b$ & $\left(6.0 \times 10^{4}\right) b$ \\
Mesotrophic & $0-4.9 \times 10^{5}$ & $0-1.2 \times 10^{5}$ & $7.7 \times 10^{2} 8.6 \times 10^{5}$ & $8.7 \times 10^{3} 9.7 \times 10^{5}$ \\
$(\mathrm{~N}=13)$ & $\left(9.1 \times 10^{4}\right) a$ & $\left(9.5 \times 10^{3}\right) a b$ & $\left(1.2 \times 10^{5}\right) a$ & $\left(2.2 \times 10^{5}\right) a b$ \\
Eutrophic & $0-7.5 \times 10^{5}$ & $0-5.6 \times 10^{4}$ & $2.0 \times 10^{3}-1.1 \times 10^{6}$ & $3.2 \times 10^{5}-1.1 \times 10^{6}$ \\
(N=5) & $\left(2.1 \times 10^{5}\right) a$ & $\left(1.3 \times 10^{4}\right) a$ & $\left(4.2 \times 10^{5}\right) a$ & $\left(6.4 \times 10^{5}\right) a$ \\
F-value & 0.336 & 3.413 & 14.559 & 8.929 \\
p-value & 0.717 & 0.047 & $<0.005$ & $<0.005$ \\
\hline
\end{tabular}

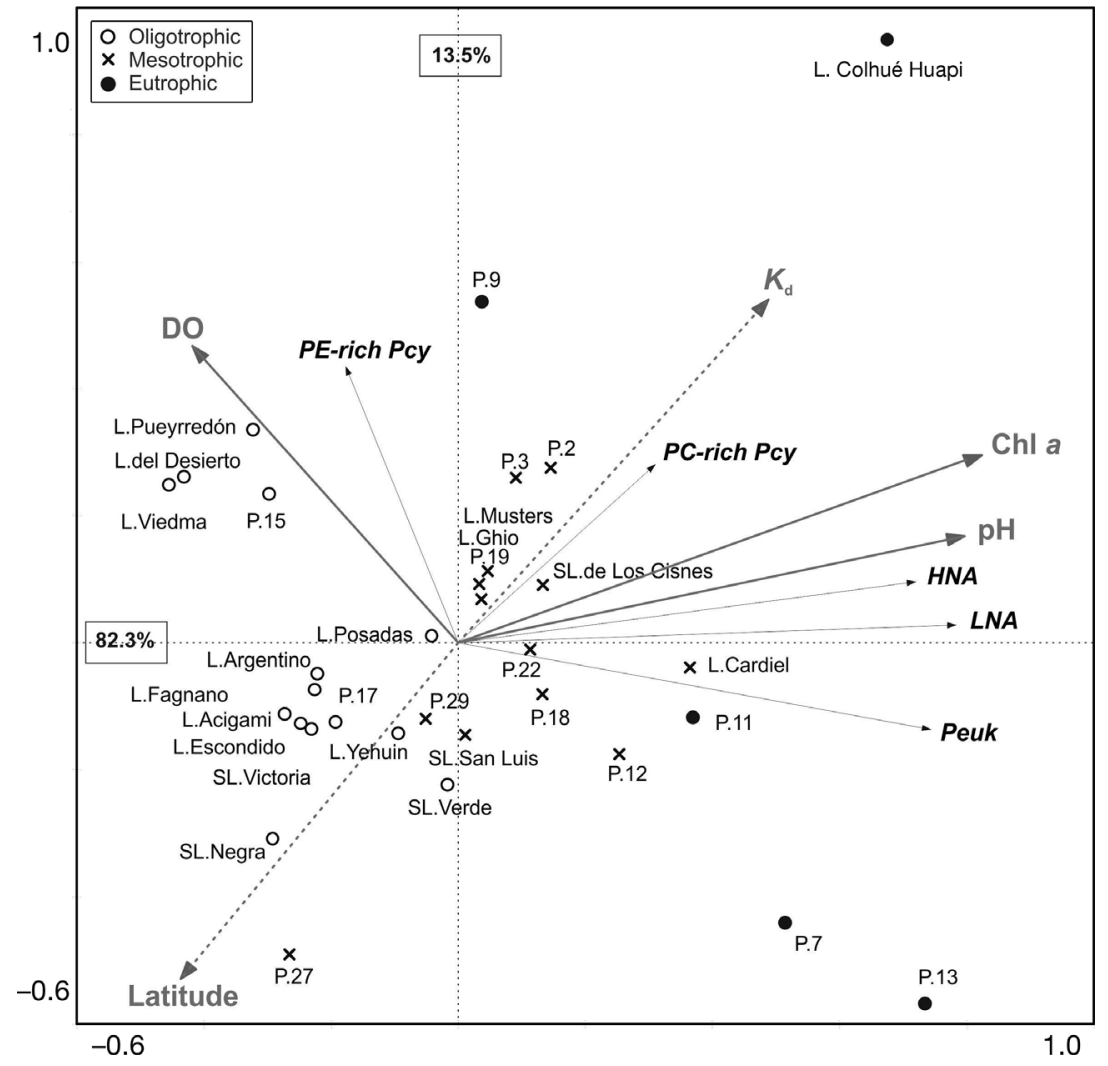

Fig. 6. Redundancy analysis (RDA) of Patagonian water bodies based on the total abundance of each picoplankton fraction (thin arrows) and environmental data (thick arrows). Significant environmental variables $(p<0.05)$ are indicated with solid arrows, while dotted arrows are not significant. LNA: low nucleic-acid content bacterioplankton; HNA: high nucleic-acid content bacterioplankton; PE-rich Pcy: phycoerythrin-rich picocyanobacteria; PC-rich Pcy: phycocyanin-rich Pcy; Peuk: picoeukaryotes; DO: dissolved oxygen; $K_{\mathrm{d}}$ : vertical attenuation coefficient of photosynthetically active radiation; chl a: chlorophyll a concentration. See Table 1 for water body identifications

higher oxygen levels. All the lakes from Tierra del Fuego were placed together with higher latitude values in the lower-left quadrant of the figure.
The ratios of HB:PPP abundances showed a positive and significant correlation to chl a values $(\mathrm{r}=0.40$, $\mathrm{p}<0.03)$, suggesting proportionally higher abundances of heterotrophic PP as compared to those of autotrophic PP with increasing trophic status.

\section{Cytometric diversity}

Between 2 and 6 different cytometric populations of HB were identified in each of the 32 water bodies (Table 4). The classification of all populations by cluster analysis using the different flow cytometer signals (SSC, FL1, FL3) allowed the identification of 28 different cytometric populations of HB that appeared in 1 or more water system (as explained above, those that were $<60 \%$ different were considered to be the same population in different lakes). The number of HB populations and the Simpson diversity index did not show any relationship with the environmental variables studied.

We observed between 1 and 8 PPP cytometrically-defined populations per water body (Table 4) that varied in SSC and/or pigment content (Fig. 7). Similarly to $\mathrm{HB}$, cluster analysis using the different flow cytometer signals of PPP allowed the identification of 14 different cytometric populations of PE-rich Pcy, 8 of PC-rich Pcy and 41 of Peuk among the 32 Patagonian water bodies. The number of PC-rich populations showed a 
mean value of 1.2 in eutrophic water bodies (Table 4) and was positively related to chl a concentration ( $\mathrm{r}=0.51$, $\mathrm{p}$ $=0.003$ ), while the number of PE-rich populations showed a mean value of 1.3 in oligotrophic lakes (Table 4) and was negatively related to temperature ( $r=-0.38, p=0.030)$. Furthermore, the Simpson index of PPP diversity was positively correlated to $\mathrm{chl}$ a $(\mathrm{r}=0.47$, $\mathrm{p}=0.007)$ and negatively correlated to DO $(r=-0.50, p=0.003)$.

The result of the CCA analysis using the abundance of each cytometricallyderived PP population (28 HB, 13 PErich Pcy, 8 PC-rich Pcy and 42 Peuk populations) and the environmental variables is shown in Fig. 8. The first 2 axes accounted for $63.2 \%$ of the variance (Axis 1: 36.9\%, Axis 2: $26.3 \%$ ). The environmental variables were significantly correlated to the first axis ( $p=0.04$ ), and the test of significance of all canonical axes was also significant $(\mathrm{p}=0.008)$. The first axis was mainly defined by chl $a$ and DO (intraset correlation coefficients 0.91 and -0.46 , respectively); the second axis was mainly correlated to latitude and $\mathrm{pH}$ (intraset correlation coefficients 0.71 and -0.50 , respectively). This analysis indicated the separation of the water bodies by latitude and trophic status and also the influence of both types of variables on the cytometrically-defined PP population abundances. Water bodies from Tierra del Fuego were ordinated towards higher latitudes and higher DO, together with some Andean lakes located in Santa Cruz Province (e.g. Lakes Viedma, Argentino, del Desierto). The eutrophic Ponds 7, 9, 11, 13 (from the Plateau) were situated together with higher levels of chl a.

The canonical variation partitioning analysis (pCCA) performed to discriminate the relative importance of the variables on the cytometrically-defined PP population abundances showed that the relative importance of non-spatial environmental factors $(\mathrm{pH}, \mathrm{chl} a$, DO) was $14.5 \%$ and the relative importance of spatial components (latitude and longitude) was $10.6 \%$, with only the non-spatial environmental factors being significant (Monte Carlo permutation test $\mathrm{p}<0.05$ ).
Table 4. Number of cytometrically defined populations of heterotrophic bacterioplankton $(\mathrm{HB})$ and photosynthetic picoplankton (phycoerythrin [PE]-rich picocyanobacteria [Pcy], phycocyanin [PC]-rich Pcy, and picoeukaryotes Per water body, as well as ranges and averages among all (32) Patagonian water bodies and in oligotrophic, mesotrophic and eutrophic water bodies. Ranges represent maximum and minimum values, and means are expressed in parentheses. na: value not available. Water body abbreviations are explained in Table 1

\begin{tabular}{|c|c|c|c|c|}
\hline Water body & $\mathrm{HB}$ & PE-rich Pcy & PC-rich Pcy & Peuk \\
\hline L.Musters & 4 & 2 & 0 & 2 \\
\hline P.2 & 4 & 0 & 0 & 3 \\
\hline P.3 & 5 & 1 & 2 & 4 \\
\hline L.Colhué Huapi & na & 1 & 2 & 2 \\
\hline L.Pueyrredón & 3 & 2 & 0 & 1 \\
\hline L.Posadas & 5 & 2 & 0 & 4 \\
\hline P.7 & 4 & 0 & 1 & 3 \\
\hline L.Ghio & 3 & 1 & 1 & 2 \\
\hline P.9 & 2 & 1 & 2 & 2 \\
\hline P.11 & 2 & 2 & 1 & 3 \\
\hline P.12 & 5 & 1 & 0 & 6 \\
\hline P.13 & 6 & 0 & 0 & 4 \\
\hline L.Cardiel & 6 & 2 & 0 & 3 \\
\hline P.15 & 3 & 1 & 1 & 3 \\
\hline L.del Desierto & 4 & 1 & 0 & 3 \\
\hline P.17 & 6 & 1 & 0 & 4 \\
\hline P.18 & 3 & 1 & 1 & 6 \\
\hline P.19 & 2 & 0 & 1 & 4 \\
\hline L.Viedma & 5 & 1 & 0 & 1 \\
\hline L.Argentino & 3 & 1 & 0 & 2 \\
\hline P.22 & 4 & 1 & 1 & 2 \\
\hline L.Acigami & 5 & 1 & 0 & 1 \\
\hline SL.Negra & 4 & 0 & 1 & 4 \\
\hline L.Escondido & 6 & 3 & 0 & 3 \\
\hline L.Fagnano & 4 & 2 & 0 & 4 \\
\hline P.27 & 3 & 1 & 0 & 3 \\
\hline SL.Victoria & 3 & 1 & 0 & 4 \\
\hline P.29 & 3 & 1 & 1 & 2 \\
\hline SL.Verde & 3 & 1 & 0 & 5 \\
\hline SL.San Luis & 3 & 0 & 1 & 1 \\
\hline SL.de Los Cisnes & 5 & 0 & 0 & 1 \\
\hline L.Yehuin & 3 & 1 & 0 & 7 \\
\hline All water bodies & $2-6(3.9)$ & $0-3(1.0)$ & $0-2(0.5)$ & $1-7(3.1)$ \\
\hline Oligotrophic & $3-6(4.1)$ & $0-3(1.3)$ & $0-1(0.1)$ & $1-7(3.3)$ \\
\hline Mesotrophic & $2-6(3.8)$ & $0-2(0.8)$ & $0-2(0.6)$ & $1-6(3.0)$ \\
\hline Eutrophic & $2-6(3.5)$ & $0-2(0.8)$ & $0-2(1.2)$ & $2-4(2.8)$ \\
\hline
\end{tabular}

\section{DISCUSSION}

We used FC to obtain an integral view of PP structure in water bodies located along a trophic and latitudinal gradient, integrating bacteria and PPP, making an effort not to ignore groups because of methodological or practical difficulties. The advantage of FC over microscopy is its capacity to obtain cellspecific measurements in large numbers of cells with limited effort. While it has limitations ( 1000 bacteria $\mathrm{ml}^{-1}$ and 120 PPP $\mathrm{ml}^{-1}$ are needed to be detected by the cytometer as a homogeneous population), it pro- 

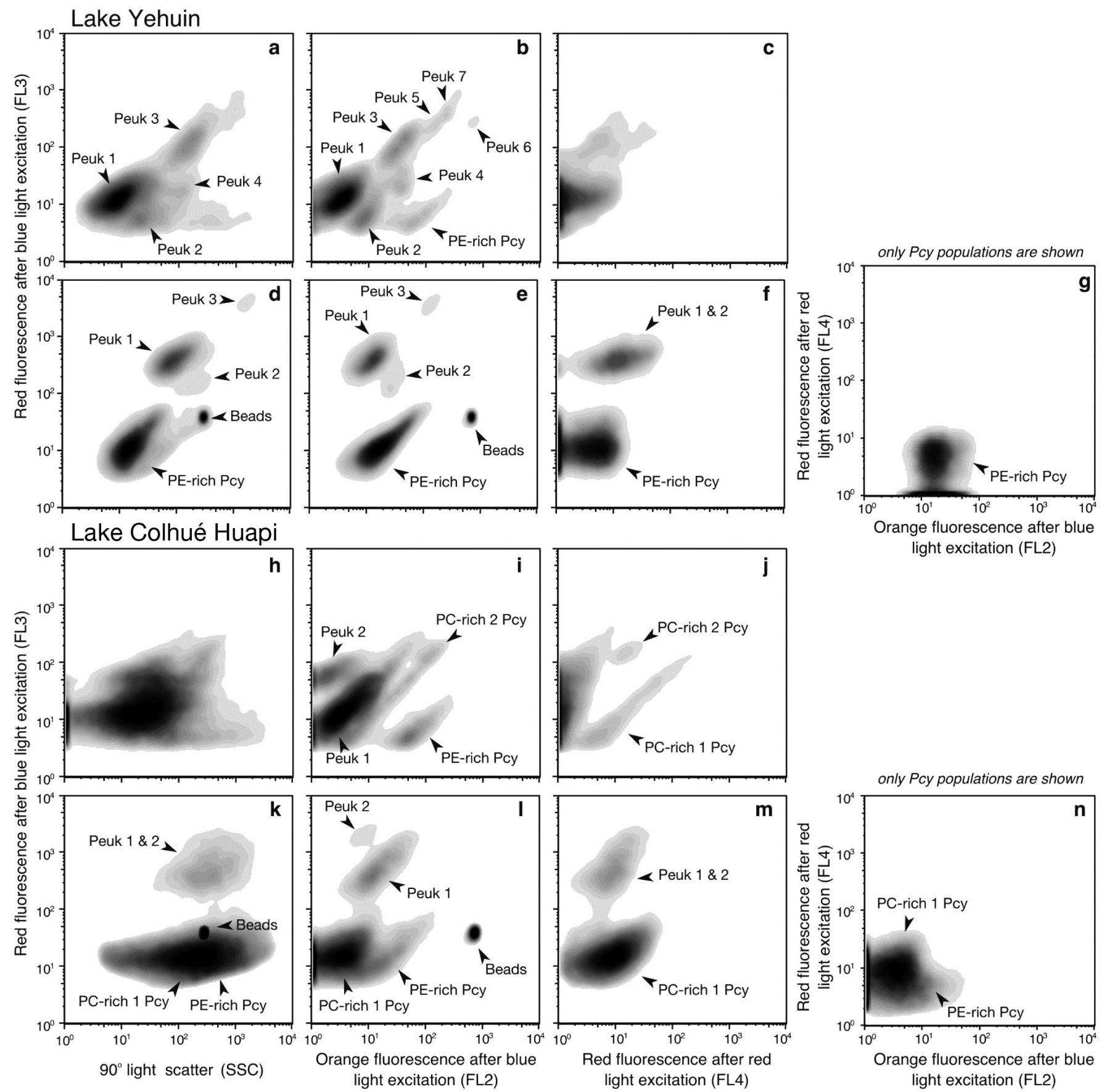

Fig. 7. Cytograms showing the different photosynthetic picoplankton populations (in unstained samples) of (a-g) oligotrophic and transparent Lake Yehuin (October 2008) dominated by PE-rich Pcy, and (h-n) eutrophic and turbid Lake Colhué Huapi (November 2007) dominated by PC-rich Pcy. Different Peuk were also presented in both lakes. SSC: side scatter; see Fig. 6 legend for explanation of other abbreviations

vides more information than classical epifluorescence microscopy. The values are statistically sounder and the different populations are determined more objectively. In fact, we could identify an average of 4.6 different PPP and 3.9 different HB populations per sample, while this would have been impossible with epifluorescence. Still, neither aerobic anoxygenic bacteria (although the anaerobic bacteria can be enumerated, Casamayor et al. 2007) nor proteorhodopsincontaining bacteria can be detected yet with FC. It is not clear, however, whether these organisms can be considered true autotrophs, or use the light for other reasons (e.g. Fuhrman et al. 2008). In any case, the absolute abundances obtained by FC and epifluores- 


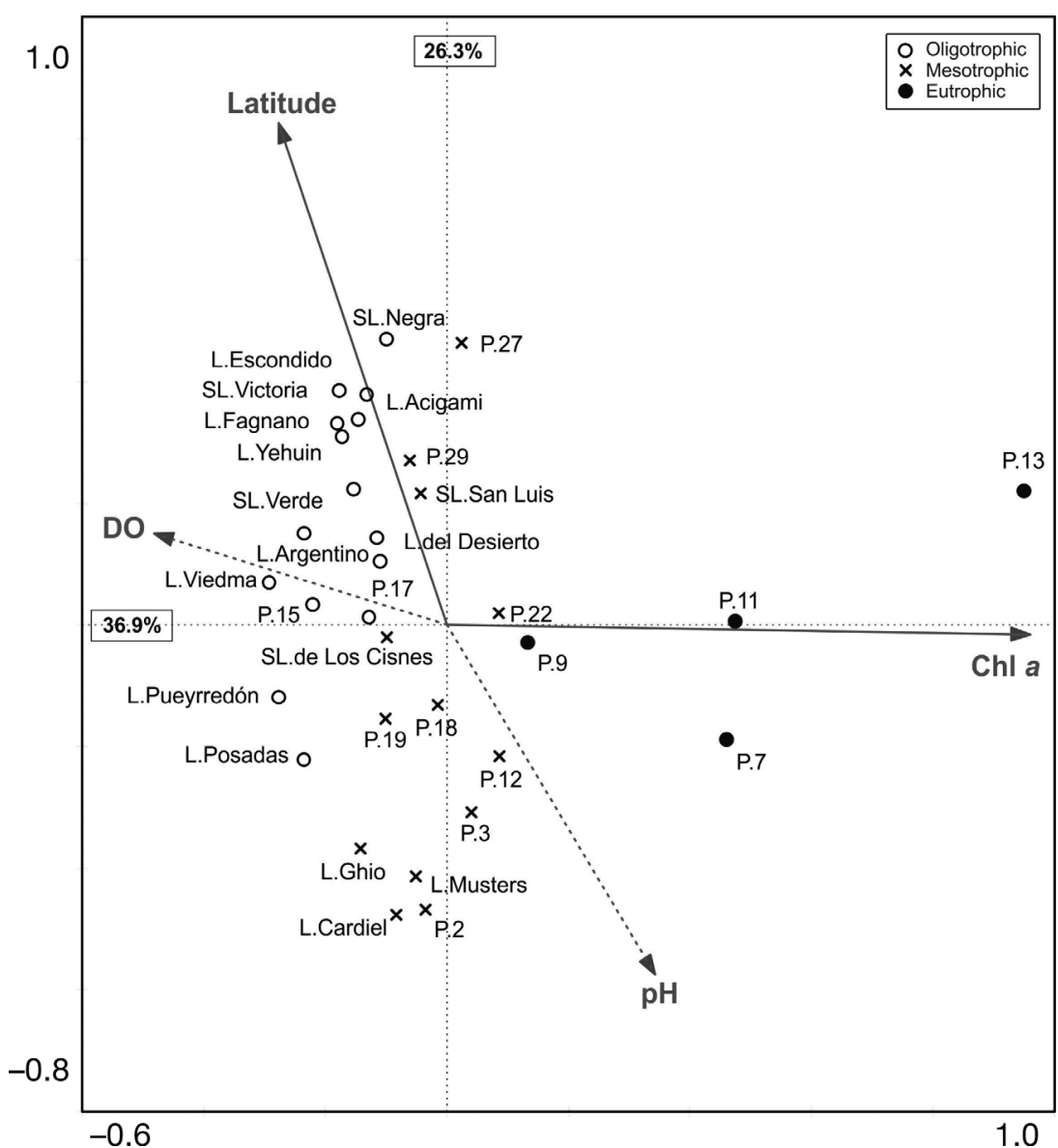

Fig. 8. Canonical correspondence analysis (CCA) of Patagonian water bodies based on the abundances of each identified picoplankton population (28 different cytometric populations of heterotrophic bacterioplankton, 13 of phycoerythrin-rich picocyanobacteria, 8 of phycocyanin-rich picocyanobacteria and 42 of picoeukaryotes) and environmental data. Significant environmental variables $(\mathrm{p}<0.05)$ are indicated with solid arrows, while dotted arrows are not significant. DO: dissolved oxygen; see Table 1 for water body identifications

cence were well correlated in our study, as others have found elsewhere (e.g. Gasol et al. 1999).

\section{Heterotrophic bacterioplankton}

The presence of distinct NA-content fractions in $\mathrm{HB}$ has been reported for a wide range of aquatic ecosystems (e.g. Button et al. 1996, Gasol \& del Giorgio 2000, Jochem 2001, Calvo-Díaz \& Morán 2006, Bouvier et al. 2007, Sarmento et al. 2008, Wang et al. 2009) and has thus been assumed to be a general feature of bacterioplankton communities. However, it is now believed that these fractions are not associated with a specific activity level or to a particular cell size, but rather appear to be related to different phylogenetic compositions (e.g. Zubkov et al. 2001,
Wang et al. 2009, Vila-Costa et al. 2012). The FL1 emission of individual cells is primarily related to the intracellular NA content (Bouvier et al. 2007) but also to genome size (which varies greatly between species), number of genome copies, and chromosomal topology (related to the cellular physiologic condition), that may greatly influence the average fluorescence emission of stained bacterial cells, and are likely to vary in ways which reflect phylogenetic bacterial properties (Button \& Robertson 1989, Lebaron \& Joux 1994, Schattenhofer et al. 2011).

The abundances of total HB are commonly related to chl a concentration, both in marine and freshwater systems (Bird \& Kalff 1984, Cole et al. 1988, Gasol \& Duarte 2000). We found that the abundances of total $\mathrm{HB}$ and those of LNA and HNA bacteria increased with the increasing trophic status of the water bodies (Fig. 3). It is remarkable that both groups of bacteria showed a very similar response to chl $a$, with very similar log-log slopes (0.49 \pm 0.09 for LNA and $0.51 \pm 0.1$ for HNA), whereas in some previous studies LNA were very unresponsive to changes in chl a (e.g. Li et al. 1995). These previous results suggested that LNA bacteria were dormant or not very active, and the ratio between both groups of cells (\%HNA) was initially used as an indicator of bacterial activity (Jellett et al. 1996, Gasol et al. 1999). Since both LNA and HNA responded similarly to chl $a$ in our studied lakes, the ratio HNA:LNA was unresponsive to increasing chl a and did not serve as an indicator of trophic status, unlike the findings of other studies (Calvo-Díaz et al. 2004, Morán et al. 2007). We also found no relationship between the average fluorescence of total $\mathrm{HB}$, or that of the HNA or LNA fractions, and indices of trophic status (details not shown), while we had previously shown that the studied water bodies harbored different bacterial community compositions that were associated with differences in latitude and trophic status (Schiaffino et al. 2011). The covariation of HNA and LNA bacteria in these water bodies is thus interesting and deserves closer scrutiny, in studies integrating FC and bacterial phylogenetic composition data, which was however beyond the scope of this study. 
In addition, we found that HB (both LNA and HNA) abundances were negatively related to latitude and positively related to temperature. Other authors reported that abundances of HB correlate to temperature both in lakes and oceans (e.g. Caron et al. 1985, Murphy \& Haugen 1985, Jochem 1988, Maeda et al. 1992, Coveney \& Wetzel 1995, Li 1998). Temperature, which was inversely related to latitude in our study, is in general associated with the growth rate of heterotrophic and autotrophic microorganisms (Pomeroy \& Deibel 1986, White et al. 1991, Callieri \& Stockner 2002).

\section{Photosynthetic picoplankton}

PPP abundance showed a positive and significant relationship with $\mathrm{pH}$. The relationship between the global abundance of all PPP and chl a content was weak, but the abundance of Peuk and that of PC-rich Pcy correlated positively and significantly to chl a. A similar relationship had been reported by Vörös et al. (1998) in a set of lakes of the northern hemisphere and by Callieri et al. (2007) in a study that included some North Patagonian ultra-oligotrophic deep lakes.

In addition, the trophic status of the water bodies was crucial in determining the most abundant picocyanobacterial pigment composition, as in Vörös et al. (1998). Pcy with different pigment composition (PC and PE) have different capacities to capture distinct wavelengths (Callieri 1996) and therefore occupy different light spectrum niches (Stomp et al. 2004). Callieri (1996) and Vörös et al. (1998) found that PErich cells dominate in clear waters whereas PC-rich cells dominate in turbid waters. Stomp et al. (2007) found that both types of cells coexist in waters of intermediate turbidity when studying Pcy abundance in 70 diverse aquatic ecosystems. In our study, the PE-rich cells were more abundant and widespread than the PC-rich cells (average PE-rich:PCrich ratio of 12.1). Seven water bodies had no PE-rich Pcy, while 19 water bodies had no PC-rich Pcy. Three water bodies had no Pcy, and only Peuk, which were present in all types of water bodies. The relative contribution of PE-rich to total Pcy cells (PE-rich:Pcy ratio) was higher in more oligotrophic and transparent lakes, whereas the PC-rich cells tended to be relatively more abundant in the turbid and eutrophic water bodies.

The quality and quantity of light in the water column is another factor determining the structure and dynamics of PPP (Callieri 1996, Vörös et al.
1998), and the particular nutritional and light requirements of Pcy are very different from those of Peuk (Weisse 1993). Craig (1987) showed the importance of light in explaining the dominance of Peuk over Pcy in less transparent, eutrophic lakes. In addition, Pick \& Agbeti (1991) found that the contribution of Peuk to total picoplanktonic biomass increases with the light extinction coefficient. Similarly, Vörös et al. (2009) suggested that Peuk are better competitors than Pcy at low light and temperature, a pattern that had already been observed in the ocean (Glover et al. 1986). In agreement to these data, our study found that Peuk prevailed over Pcy with increasing $K_{\mathrm{d}}$ and trophic status (chl a concentration). The relationship between Peuk abundance and chl $a$ was particularly strong $\left(\mathrm{R}^{2}=0.38\right.$, log-log slope $\left.=0.75\right)$.

Doolittle et al. (2008) found a general trend of decreasing abundance of PPP (PE-rich Pcy and Peuk) as latitude increases in the Atlantic sector of the Southern Ocean. In line with this finding, we observed a negative and significant relationship between PPP abundance and latitude in the gradient of studied lakes.

The wide dispersion in SSC signal observed for Pcy populations in 15 out of 32 samples in the present study was in agreement with results reported for Lake Mondsee, Austria by Crosbie et al. (2003), who further observed that sorted cells of Pcy-A (Low-SSC) and Pcy-B (High-SSC) populations are indistinguishable when viewed by epifluorescence microscopy. The cause of the high SSC values is presently not known, but these cannot be related to cell doublets or microcolonies ( $\geq 4$ picocyanobacterial cells) as those would have increased fluorescence simultaneously with the increase in scatter. Crosbie et al. (2003) suggested that increased scatter could be due to calcite deposition on the surface (particularly the S-layer) of photosynthetically active cyanobacterial PP (e.g. Thompson et al. 1997). In our study, we observed a significant correlation between the relative abundance of High-SSC Pcy and chl a concentration which allows us to hypothesize that in the more eutrophic and complex ecosystems some of the Pcy might have more conspicuous external structures to which calcite or other particle types can attach. In fact, using atomic force microscopy Malfatti \& Azam (2009) observed that Synechococcus and other soconsidered 'free-living' bacteria are intimately associated with other bacteria at nanometer scales and that presumably inorganic nanoparticles are in close contact with the cells. A. Malits (unpubl. data) also observed that bacteria in the presence of black carbon inorganic particles increased their side scatter 
without changing their green fluorescence, evidence that supports the Crosbie et al. (2003) proposal.

\section{Heterotrophic and photosynthetic picoplankton abundances along environmental gradients}

In the water bodies that we sampled, morphometry, trophic status and location of the water bodies (i.e. Andean versus Plateau lakes) are to a large extent related variables, since most Andean water bodies are oligotrophic and deep, whereas the Plateau water bodies tend to be meso-eutrophic and relatively shallow. The spatial dimension may be correlated to crucial local environmental variables that affect the PP communities (e.g. Sommaruga \& Casamayor 2009). Nevertheless, the covariation between the spatial distribution and the local environmental factors can be separated somewhat by using multivariate analyses (e.g. Beisner et al. 2006, Langenheder \& Ragnarsson 2007, Van der Gucht et al. 2007, Schiaffino et al. 2011). In our study, the result of the multivariate analysis considering all PP groups together (total abundances of LNA, HNA, PE-rich Pcy, PC-rich Pcy and Peuk) showed that the location of the water bodies (Andean versus Plateau) and thus, the trophic status of the lakes, was important in shaping PP abundances. PC-rich Pcy, Peuk, HNA and LNA presented higher abundances in water bodies with higher values of $\mathrm{pH}, \mathrm{chl} a$ and $K_{\mathrm{d}}$ (typically from the Plateau), whereas PE-rich Pcy shower higher abundances in oligotrophic diluted and clear water bodies with higher DO values (typically Andean lakes). In agreement with this result, other studies of oligotrophic deep lakes (e.g. subalpine and north Patagonian lakes) have shown that in general these environments have PPP communities dominated by PE-rich Pcy, whereas PC-rich Pcy and Peuk are rare or less abundant (Zunino \& Diaz 2000, Callieri 2008).

The ratios between the abundances of HB and PPP increased with increasing chl $a$, suggesting higher abundances of heterotrophic PP than autotrophic PP with increasing trophic status. A similar trend was reported by Burns \& Galbraith (2007) for New Zealand water bodies.

\section{Cytometric diversity}

Although cytometric group diversity, as measured in the present study, cannot provide information about numbers of species of PP that inhabit these lakes, the signal provided by the flow cytometer revealed interesting and indeed remarkable biogeographic patterns in PP structure. Previous FC studies in large lakes were not able to identify such a variation in the number of cytometric populations inhabiting the lakes. Crosbie et al. (2003) identified 3 to 5 populations in subalpine Lake Mondsee, Sarmento et al. (2008) identified 3 PE-rich Pcy populations that likely were aggregates of the same phylogenetic type in Lake Kivu (east Africa), and Stenuite et al. (2009) identified 2 Peuk populations in Lake Tanganyika. The large diversity of Peuk populations that we observed ( 1 to 7 , average 3 per lake) is remarkable in comparison with these other studied lakes. Peuk tend to be less abundant than Pcy in marine systems (Li 2009), and are also less abundant than Pcy in lakes Kivu, Tanganyika and Mondsee (Crosbie et al. 2003, Sarmento et al. 2008, Stenuite et al. 2009). However Peuk were more abundant than Pcy in our lakes (average $1.2 \times 10^{5} \mathrm{Peuk} \mathrm{ml}^{-1}$ and $1.0 \times$ $10^{5} \mathrm{Pcy} \mathrm{m}^{-1}$ ). This discrepancy might be due to the higher average trophic status of lakes considered in this study. In our dataset, the ratio Pcy:Peuk increased with DO and lake area (log-log slope $=0.43$ ) and decreased with chl $a_{\text {; }}$ large oligotrophic lakes have more Pcy and smaller eutrophic lakes have more Peuk.

In spite of the relatively low number of Pcy populations (between 0 and 3, average 1.5) that could be detected by FC in each sample, it is remarkable that the number of Pcy populations followed the same patterns observed as for the abundance. That is, the number of PC-rich populations per sample increased with increasing trophic status. Moreover, PPP diversity (Simpson index) also increased with the trophic status of the lakes ( $\mathrm{chl}$ a). This result is in line with that reported by Li (1997), who studied the cytometric cell-based diversity of marine ultraphytoplankton (photosynthetic nanoplankton and PP) and found that this cytometric diversity increases with higher values of chl $a$.

The number of HB populations and Simpson's diversity index of cytometrically-derived bacterial groups, however, did not show any relationship with the environmental variables studied. However, all HB cytograms from large deep oligotrophic lakes were almost identical (data not shown). This similarity among oligotrophic Patagonian lakes agrees with a previous study of bacterioplankton structure using a molecular fingerprinting technique (Schiaffino et al. 2011). Strikingly, the comparison among bacterial samples using completely different techniques, DGGE bands patterns (Schiaffino et al. 2011) and cytograms (present study), gave the same result. 
Results of the CCA multivariate analysis using the abundances of all PP populations identified are also in line with those reported by Schiaffino et al. (2011), showing that variables related to trophic status ( $\mathrm{chl} \mathrm{a}$ ) and latitude are significant in determining the PP cytometric population abundances and diversity. However, the canonical variation partitioning approach (pCCA) that enables discrimination between the influences of different types of factor, showed that environmental variables exerted a significant and stronger influence $(14.5 \%)$ than geographic position (latitude and longitude, 10.6\%). Nevertheless, the geographic matrix analyzed in the pCCA contained not only latitude but also longitude, a variable representing in part the west-east trophic gradient of water bodies (Fig. 2), so that the relative importance of latitude alone could not be estimated.

In summary, our study shows a strong influence of environmental factors (mainly variables related to trophic status: chl $a, \mathrm{pH}, \mathrm{DO})$, and a less marked effect of latitude, on PP structure. HB and PPP abundances decreased towards higher latitudes, but their diversity indexes did not, whereas HB and PPP (particularly PC-rich Pcy and Peuk) abundances, together with PPP Simpson diversities increased with higher values of chl a. PE-rich Pcy were more abundant and showed higher number of cytometric populations in oligotrophic water bodies, whereas PC-rich Pcy did so in eutrophic ones, as previously reported for the northern hemisphere. Peuk prevailed over Pcy with increasing trophic status and light attenuation coefficient of the water bodies, and HB prevailed over PPP with increasing trophic status.

Acknowledgements. This work was funded by a grant of the Argentinean Funds for Technical and Scientific Investigation (FONCYT, PICT 32732) and the Program 'Luis Santaló' of the National Research Council of Spain and the National Council of Scientific and Technical Research of Argentina (CSIC-CONICET, PROBA 2007AR0018). We thank Dr. Guillermo Tell, Dr. Rodrigo Sinistro, Dr. M. Laura Sánchez and Mr. Adrián Rua for their collaboration during the field campaigns, and Dr. Ramon Massana (ICM) for general support.

\section{LITERATURE CITED}

Agawin NSR, Duarte CM, Agustí S (2000) Nutrient and temperature control of the contribution of picoplankton to phytoplankton biomass and production. Limnol Oceanogr 45:591-600

Azam F, Fenchel T, Field JG, Gray JS, Meyer-Riel RA, Thingstad F (1983) The ecological role of water-column microbes in the sea. Mar Ecol Prog Ser 10:257-263

Beisner BE, Peres-Neto PR, Lindström ES, Barnett A, Longhi
ML (2006) The role of environmental and spatial processes in structuring lake communities from bacteria to fish. Ecology 87:2985-2991

Bell T, Kalff J (2001) The contribution of picophytoplankton in marine and freshwater systems of different trophic status and depth. Limnol Oceanogr 46:1243-1248

Berthet P, Gérard G (1965) A statistical study of microdistribution of Oribatei (Acari). Part I. The distribution patterns. Oikos 16:214-227

> Bird DJ, Kalff J (1984) Empirical relationships between bacterial abundance and chlorophyll concentration in fresh and marine waters. Can J Fish Aquat Sci 41:1015-1023

Borcard D, Lengendre P, Drapeau P (1992) Partialling out the spatial component of ecological variation. Ecology 73:1045-1055

Bouvier T, del Giorgio PA, Gasol JM (2007) A comparative study of the cytometric characteristics of high and low nucleic-acid bacterioplankton cells from different aquatic ecosystems. Environ Microbiol 9:2050-2066

> Buck KR, Chavez FP, Campbell L (1996) Basin-wide distributions of living carbon components and the inverted trophic pyramid of the central gyre of the North Atlantic Ocean, summer 1993. Aquat Microb Ecol 10:283-298

Burns CW, Galbraith LM (2007) Relating planktonic microbial food web structure in lentic freshwater ecosystems to water quality and land use. J Plankton Res 29:127-139

Burns CW, Stockner JG (1991) Picoplankton in 6 NewZealand lakes: abundance in relation to season and trophic state. Int Rev Gesamten Hydrobiol 76:523-536

Button DK, Robertson BR (1989) Kinetics of bacterial processes in natural aquatic systems based on biomass as determined by high-resolution flow-cytometry. Cytometry 10:558-563

Button DK, Robertson BR, Juttner F (1996) Microflora of a subalpine lake: bacterial populations, size and DNA distributions, and their dependence on phosphate. FEMS Microbiol Ecol 21:87-101

Callieri C (1996) Extinction coefficient of red, green and blue light and its influence on picocyanobacterial types in lakes at different trophic levels. Mem Ist Ital Idrobiol 54:135-142

Callieri C (2008) Picophytoplankton in freshwater ecosystems: the importance of small-sized phototrophs. Freshw Rev 1:1-28

> Callieri C (2010) Single cells and microcolonies of freshwater picocyanobacteria: a common ecology. J Limnol 69:257-277

Callieri C, Stockner JG (2002) Freshwater autotrophic picoplankton: a review. J Limnol 61:1-14

> Callieri C, Modenutti BE, Queimaliños CP, Bertoni R, Balseiro EG (2007) Production and biomass of picophytoplankton and larger autotrophs in Andean ultraoligotrophic lakes: differences in light harvesting efficiency in deep layers. Aquat Ecol 41:511-523

> Callieri C, Caravati E, Corno G, Bertoni R (2012) Picocyanobacterial community structure and space-time dynamics in the subalpine Lake Maggiore (N. Italy). J Limnol 71:95-103

Calvo-Díaz A, Morán XAG (2006) Seasonal dynamics of picoplankton in shelf waters of the southern Bay of Biscay. Aquat Microb Ecol 42:159-174

Calvo-Díaz A, Morán XAG, Nogueira E, Bode A, Varela M (2004) Picoplankton community structure along the northern Iberian continental margin in late winter-early spring. J Plankton Res 26:1069-1081 
Camacho A, Miracle MR, Vicente E (2003) Which factors determine the abundance and distribution of picocyanobacteria in inland waters? A comparison among different types of lakes and ponds. Arch Hydrobiol 157: 321-338

Caron DA, Pick FR, Lean DRS (1985) Chroococcoid cyanobacteria in Lake Ontario: seasonal and vertical distribution during 1982. J Phycol 21:171-175

Casamayor EO, Ferrera I, Cristina X, Borrego CM, Gasol JM (2007) Flow cytometric identification and enumeration of photosynthetic sulfur bacteria and potential for ecophysiological studies at the single-cell level. Environ Microbiol 9:1969-1985

Chisholm SW, Olson RJ, Zettler ER, Goericke R, Waterbury JB, Welschmeyer NA (1988) A novel free living prochlorophyte abundant in the oceanic euphotic zone. Nature 334:340-343

- Cole JJ, Findlay S, Pace ML (1988) Bacterial production in fresh and saltwater ecosystems: a cross-system overview. Mar Ecol Prog Ser 43:1-10

Cotner JB, Biddanda BA (2002) Small players, large role: microbial influence on biogeochemical processes in pelagic aquatic ecosystems. Ecosystems 5:105-121

Cottenie K (2005) Integrating environmental and spatial processes in ecological community dynamics. Ecol Lett 8: 1175-1182

> Coveney MF, Wetzel RG (1995) Biomass, production and specific growth rate of bacterioplankton and coupling to phytoplankton in an oligotrophic lake. Limnol Oceanogr 40:1187-1200

Craig SR (1987) The distribution and contribution of picoplankton to deep photosynthetic layers in some meromictic lakes. Acta Acad Aboensis 47:55-81

Crosbie ND, Teubner K, Weisse T (2003) Flow-cytometric mapping provides novel insights into the seasonal and vertical distributions of freshwater autotrophic picoplankton. Aquat Microb Ecol 33:53-66

Daley RJ, Hobbie JE (1975) Direct counts of aquatic bacteria by a modified epifluorescence technique. Limnol Oceanogr 20:875-882

del Giorgio PA, Gasol JM (1995) Biomass distribution in freshwater plankton communities. Am Nat 146:135-152

> Descy JP, Sarmento H, Higgins HW (2009) Variability of phytoplankton pigment ratios across aquatic environments. Eur J Phycol 44:319-330

- Díaz MM, Pedrozo F, Baccala N (2000) Summer classification of Southern Hemisphere temperate lakes. Lake Reservoir Manag 5:213-229

Doolittle DF, Li WKW, Wood AM (2008) Wintertime abundance of picoplankton in the Atlantic sector of the Southern Ocean. Nova Hedwigia 133:147-160

Friedrich U, Schallenberg M, Holliger C (1999) Pelagic bacteria-particle interactions and community-specific growth rates in four lakes along a trophic gradient. Microb Ecol 37:49-61

> Fuhrman JA, Schwalbach MS, Stingl U (2008) Proteorhodopsins: an array of physiological roles? Nat Rev Microbiol 6:488-494

Gasol JM, del Giorgio PA (2000) Using flow cytometry for counting natural planktonic bacteria and understanding the structure of planktonic bacterial communities. Sci Mar 64:197-224

Gasol JM, Duarte CM (2000) Comparative analyses in aquatic microbial ecology: How far do they go? FEMS Microbiol Ecol 31:99-106
Gasol JM, del Giorgio PA, Duarte CM (1997) Biomass distribution in marine planktonic communities. Limnol Oceanogr 42:1353-1363

- Gasol JM, Zweifel UL, Peters F, Fuhrman JA, Hagström A (1999) Significance of size and nucleic acid content heterogeneity as measured by flow cytometry in natural planktonic bacteria. Appl Environ Microbiol 65: 4475-4483

Glover HE, Keller MD, Guillard RRL (1986) Light quality and oceanic ultraplankters. Nature 319:142-143

Hall JA, Vincent WF (1994) Vertical and horizontal structure of the picophytoplankton community in a stratified coastal system off New Zealand. NZ J Mar Freshw Res 28:299-308

> Jellett JF, Li WKW, Dickie PM, Boraie A, Kepkay PE (1996) Metabolic activity of bacterioplankton communities assessed by flow cytometry and single carbon substrate utilization. Mar Ecol Prog Ser 136:213-225

Jochem E (1988) On the distribution and importance of picocyanobacteria in a boreal inshore area (Kiel Bight, Western Baltic). J Plankton Res 10:1009-1022

Jochem FJ (2001) Morphology and DNA content of bacterioplankton in the northern Gulf of Mexico: analysis by epifluorescence microscopy and flow cytometry. Aquat Microb Ecol 25:179-194

Johnson PW, Sieburth JMcN (1982) In-situ morphology and occurrence of eukaryotic phototrophs of bacterial size in the picoplankton of estuarine and oceanic waters. J Phycol 18:318-327

Kirk JTO (1994) Light and photosynthesis in aquatic ecosystems. Cambridge University Press, Cambridge

Langenheder S, Ragnarsson H (2007) The role of environmental and spatial factors for the composition of aquatic bacterial communities. Ecology 88:2154-2161

> Lebaron P, Joux F (1994) Flow cytometric analysis of the cellular DNA content of Salmonella typhimurium and Alteromonas haloplanktis during starvation and recovery in seawater. Appl Environ Microbiol 60:4345-4350

Legendre P, Legendre L (1998) Numerical ecology. Elsevier Science, Amsterdam

Li WKW (1997) Cytometric diversity in marine ultraphytoplankton. Limnol Oceanogr 42:874-880

> Li WKW (1998) Annual average abundance of heterotrophic bacteria and Synechococcus in surface ocean waters. Limnol Oceanogr 43:1746-1753

Li WKW (2009) Plankton populations and communities. In: Witman JD, Roy K (eds) Marine macroecology. University of Chicago Press, Chicago, IL, p 29-64

Li WKW, Jellett JF, Dickie PM (1995) DNA distributions in planktonic bacteria stained with TOTO or TO-PRO. Limnol Oceanogr 40:1485-1495

Lomas MW, Bronk DA, van den Engh G (2011) Use of flow cytometry to measure biogeochemical rates and precesses in the ocean. Annu Rev Mar Sci 3:537-566

> Maeda H, Kawai A, Tilzer MM (1992) The water bloom of cyanobacterial picoplankton in Lake Biwa, Japan. Hydrobiologia 248:93-103

> Malfatti F, Azam F (2009) Atomic force microscopy reveals microscale networks and possible symbioses among pelagic marine bacteria. Aquat Microb Ecol 58:1-14

Margalef R (1968) Perspectives in ecological theory. University of Chicago Press, Chicago, IL

Marker AFH, Nush A, Rai H, Riemann B (1980) The measurement of photosynthetic pigments in freshwater and standardization of methods: conclusions and recommen- 
dations. Archives of Hydrobiology Bulletin (Ergebnisse der Limnologie) 14:91-106

> Morán XAG, Bode A, Suárez LA, Nogueira E (2007) Assessing the relevance of nucleic acid content as an indicator of marine bacterial activity. Aquat Microb Ecol 46: $141-152$

Murphy LS, Haugen EM (1985) The distribution and abundance of phototrophic ultraplankton in the North Atlantic. Limnol Oceanogr 30:47-58

Olson RJ, Vaulot D, Chisholm SW (1985) Marine phytoplankton distributions measured using shipboard flow cytometry. Deep-Sea Res 32:1273-1280

Olson RJ, Zettler ER, du Rand MD (1993) Phytoplankton analysis using flow cytometry. In: Kemp PF, Sherr BF, Sherr EB, Cole JJ (eds) Handbook of methods in aquatic microbial ecology. Lewis Publishers, Boca Raton, FL, p 175-186

Paruelo JM, Beltrán A, Jobbágy E, Sala OE, Golluscio RA (1998) The climate of Patagonia: general patterns and controls on biotic processes. Ecología Austral 8:85-101

Pick FR (1991) The abundance and composition of freshwater picocyanobacteria in relation to light penetration. Limnol Oceanogr 36:1457-1462

Pick FR, Agbeti DM (1991) The seasonal dynamic and composition of photosynthetic picoplankton communities in temperate lakes in Ontario, Canada. Int Rev Gesamten Hydrobiol 76:565-580

> Pomeroy LR (1974) The ocean's food web, a changing paradigm. BioScience 24:499-504

Pomeroy LR, Deibel D (1986) Temperature regulation of bacterial activity during the spring bloom in Newfoundland coastal water. Science 233:359-361

> Porter KG, Feig YS (1980) The use of DAPI for identifying and counting aquatic microflora. Limnol Oceanogr 25: 943-948

Porter KG, Pearl H, Hodson R, Pace ML and others (1988) Microbial interactions in lake food webs. In: Carpenter SR (ed) Complex interactions in lakes communities. Springer, New York, NY, p 209-227

Quirós R, Cuch S (1985) Relaciones entre visibilidad, fósforo total y concentración de clorofila en 32 lagos patagónicos, Argentina. Actas del XII Congreso Nacional del Agua, Mendoza, p 9

Quirós R, Drago E (1999) The environmental state of Argentinean lakes: an overview. Lakes Reservoirs: Res Manag 4:55-64

Richardson TL, Jackson GA (2007) Small phytoplankton and carbon export from the surface ocean. Science 315: 838-840

Sarmento H, Unrein F, Isumbisho M, Stenuite S, Gasol JM, Descy JP (2008) Abundance and distribution of picoplankton in tropical, oligotrophic Lake Kivu, eastern Africa. Freshw Biol 53:756-771

Schattenhofer M, Wulf J, Kostadinov I, Glöckner FO, Zubkov MV, Fuchs BM (2011) Phylogenetic characterization of picoplankton populations with high and low nucleic acid content in the North Atlantic Ocean. Syst Appl Microbiol 34:470-475

Schiaffino MR, Unrein F, Gasol JM, Massana R, Balagué V, Izaguirre I (2011) Bacterial community structure in a latitudinal gradient of lakes: the roles of spatial versus environmental factors. Freshw Biol 56:1973-1991

Sherr EB, Sherr BF (2002) Significance of predation by protists in aquatic microbial food webs. Anton Leeuw Int J G 81:293-308
Sommaruga R, Casamayor EO (2009) Bacterial 'Cosmopolitanism' and importance of local environmental factors for community composition in remote high-altitude lakes. Freshw Biol 54:994-1005

Søndergaard M (1991) Phototrophic picoplancton in temperate lakes: seasonal abundance and importance along a trophic gradient. Int Rev Gesamten Hydrobiol 76: 505-522

> Stenuite S, Tarbe AL, Sarmento H, Unrein F and others (2009) Photosynthetic picoplankton in Lake Tanganyika: biomass distribution patterns with depth, season and basin. J Plankton Res 31:1531-1544

Stockner JG (1988) Phototrophic picoplankton: an overview from marine and freshwater ecosystems. Limnol Oceanogr 33:765-775

Stockner JG (1991) Autotrophic picoplankton in freshwater ecosystems: the view from the summit. Int Rev Gesamten Hydrobiol 76:483-492

Stockner JG, Antia NJ (1986) Algal picoplankton from marine and freshwater ecosystems: a multidisciplinary perspective. Can J Fish Aquat Sci 43:2472-2503

> Stockner JG, Shortreed KS (1991) Autotrophic picoplankton: community composition abundance and distribution across a gradient of oligotrophic British Columbia and Yukon Territory lakes. Int Rev Gesamten Hydrobiol 76: 581-601

> Stomp M, Huisman J, de Jongh F, Veraart AJ and others (2004) Adaptive divergence in pigment composition promotes phytoplankton biodiversity. Nature 432:104-107

Stomp M, Huisman J, Vörös L, Pick FR, Laamanen M, Haverkamp T, Stal LJ (2007) Colorful coexistence of red and green picocyanobacteria in lakes and seas. Ecol Lett 10:290-298

ter Braak CJF (1987) Ordination. In: Jongman RHG, ter Braak CJF, van Tongeren (eds) Data analysis in community and landscape ecology. PUDOC, Wageningen, p 91-173

ter Braak CJF (1991) CANOCO: a FORTRAN program for canonical community ordination by correspondence analysis, principle components analysis and redundancy analysis. Agricultural Math Group, Wageningen

ter Braak CJF, Smilauer P (2002) CANOCO reference manual and CanoDraw for Windows urser's guide: software for canonical community ordination (version 4.5). Microcomputer Power, Ithaca, NY

> Thompson JB, Schultze-Lam S, Beveridge TJ, Des Marais DJ (1997) Whiting events: biogenic origin due to the photosynthetic activity of cyanobacterial picoplankton. Limnol Oceanogr 42:133-141

Van der Gucht K, Cottenie K, Muylaert K, Vloemans N and others (2007) The power of species sorting: local factors drive bacterial community composition over a wide range of spatial scales. Proc Natl Acad Sci USA 104: 20404-20409

- Vila-Costa M, Gasol JM, Sharma S, Moran MA (2012) Community analysis of high- and low-nucleic acid-containing bacteria in NW Mediterranean coastal waters using 16S rDNA pyrosequencing. Environ Microbiol 14: 1390-1402

> Vörös L, Callieri C, Balogh KV, Bertoni R (1998) Freshwater picocyanobacteria along a trophic gradient and light quality range. Hydrobiologia 369/370:117-125

> Vörös L, Mozés A, Somogyi B (2009) A five-year study of autotrophic winter picoplankton in Lake Alaton, Hungary. Aquat Ecol 43:727-734 
Wang Y, Hammes F, Boon N, Chami M, Egli T (2009) Isolation and characterization of low nucleic acid (LNA)-content bacteria. ISME J 3:889-902

Weisse T (1993) Dynamics of autotrophic picoplankton in marine and freshwater ecosysytems. Adv Microb Ecol 13:327-370

Weisse T, Kenter U (1991) Ecological characteristics of autotrophic picoplancton in a prealpine lake. Int Rev Gesamten Hydrobiol 76:493-504

Wetzel RG (2001) Limnology: lake and river ecosystems, 3rd edn. Elsevier Academic, San Diego, CA

Editorial responsibility: Karel Šimek, České Budějovice, Czech Republic
White PA, Kalff J, Rasmussen JB, Gasol JM (1991) The effect of temperature and algal biomass on bacterial production and specific growth rate in freshwater and marine habitats. Microb Ecol 21:99-118

Zubkov MV, Fuchs BM, Burkill PH, Amann R (2001) Comparison of cellular and biomass specific activities of dominant bacterioplankton groups in stratified waters of the Celtic Sea. Appl Environ Microbiol 67:5210-5218

Zunino I, Diaz M (2000) Autotrophic picoplankton along a trophic gradient in Andean-Patagonian lakes. Verh Int Ver Theor Angew Limnol 27:1895-1899

Submitted: September 4, 2012; Accepted: January 9, 2013 Proofs received from author(s): February 22, 2013 